\title{
Assessment of Seismic Capacity for Reinforced Concrete Frames with Perforated Unreinforced Brick Masonry Infill Wall
}

\author{
Muhammad Umar ${ }^{\text {a }}$, Syed Azmat Ali Shah ${ }^{\text {b }}$, Khan Shahzada ${ }^{c}$, Tayyab Naqash ${ }^{\text {d* }}$, \\ Wajid Ali ${ }^{\mathrm{e}}$ \\ ${ }^{a}$ Master Student, Department of Civil Engineering, University of Engineering \& Technology, Peshawar, Pakistan. \\ ${ }^{b}$ Lecturer, Centre for Disaster Preparedness and Management, University of Peshawar, Peshawar, Pakistan. \\ ${ }^{c}$ Associate Professor, Department of Civil Engineering, University of Engineering \& Technology, Peshawar, Pakistan. \\ ${ }^{d}$ Assistant Professor, Department of Civil Engineering, Islamic University of Al-Madinah Al-Munawara, Saudi Arabia. \\ ${ }^{e}$ Department of Civil Engineering, University of Engineering and Technology, Peshawar, Pakistan.
}

Received 11 September 2020; Accepted 26 November 2020

\begin{abstract}
Infill walls increase the strength and stiffness of the reinforced concrete frames, but they usually are not considering in design. However, when the infills are considered in the design, the opening for doors/windows necessitates investigation as well. This research work aims to investigate the effect of perforations (openings) in the infill walls on the performance of infilled RC frames, in other words, this research investigates the number of infill walls in infilled RC frames. Based on the current construction practices in Pakistan, two full scales perforated infilled RC frames were constructed in the laboratory. One infilled RC frame has an eccentric door and window (specimen-1) while the other has only window at its centre (specimen-2). Both the specimens were tested against reverse cyclic loading (quasi-static test). From the experimental testing, it was found that infilled RC frame having less amount of opening in infill wall has more resistance to lateral loads, have more stiffness and dissipated higher energy as compared to infilled RC frame having a significant size of the opening in infill wall. Similarly, displacement ductility $(\mu \mathrm{D})$ and Response modification factor $(\mathrm{R})$ also depend on the quantity of opening in infill wall in infilled RC frame.
\end{abstract}

Keywords: RC Frame; Masonry Infill; Perforations; Quasi-static Test; Seismic Behaviour; Cyclic Loading; Performance Levels.

\section{Introduction}

Infilled walls are provided in Reinforced Concrete $(\mathrm{RC})$ frames around the globe for insulation against temperature, moisture, noise and fire [1]. These are considered as nonstructural components and are often, therefore, usually neglected in structural analysis and design [2]. If separation joints are not provided between the infilled walls and frames, under seismic excitations, these walls might contribute to the load resisting mechanism and failure pattern of $\mathrm{RC}$ frames [3]. During an earthquake, both the positive and negative role of infilled walls on RC frames have been observed. In some cases, the infilled wall increased the strength and stiffness of RC frames [4] while in other cases, these might led to shear failure of RC frame columns [5].

It is worthy of mentioning that the absence of infilled wall in the bottom of the middle storeys may result in forming soft storey mechanism [6]. Similarly, the partial infilled wall can create short column effect [7], and

* Corresponding author: tayyab@iu.edu

http://dx.doi.org/10.28991/cej-2020-03091625

(C) 2020 by the authors. Licensee C.E.J, Tehran, Iran. This article is an open access article distributed under the terms and conditions of the Creative Commons Attribution (CC-BY) license (http://creativecommons.org/licenses/by/4.0/). 
significant damage of infilled wall creates falling hazard [8]. Different damage mechanisms of infilled frames are possible, depends on the relative stiffness, strength of the infill and the bounding frame [7, 9]. The strength of an infilled frame depends on the interaction between these two and possible to change their load resisting mechanism and failure pattern [10]. At lower drift levels, an infilled frame performs like a monolithic composite wall; at larger drift levels (when infill wall separate from the bounding frame) compressive contact stresses develop between the frame and the wall $[11,12]$.

Opening in infilled frames reduces strength, stiffness and energy dissipation of the infilled frames. Many researchers have investigated the effect of opening on the performance of RC frames through the experimental setup $[3,4,13,14]$. For damage evaluation, FEMA 306 [14] and FEMA 307 [15] identifies that openings within the infill panels are the most significant parameter affecting seismic behavior of infilled systems. Doors and windows are the two most prevalent opening types. Infilled panels with openings are best viewed as assemblies of subcomponents of the appropriate material. These subcomponents interact with the surrounding frame and can alter the frame response. Principal types of interaction that can occur are strong columns and strong piers inducing shear failure in the beams strong spandrel components reducing the ductility by causing short-column effects and infill inducing tension yielding or bar splice failures in the column. Therefore in this research, two Infilled RC frame specimen, in which in one specimen only widow opening was provided while in other both door, and window openings were provided were investigated in quasi-static loading [17-21].

This paper is organized mainly in different sections. The introduction portion is followed by the methodology, the considered specimens and material properties. Then the instrument setup is reported, which is followed by the results that incorporate failure mechanisms, backbone curves, hysteresis loops and bi-linear idealizations. The performance levels are also calculated for these specimens, and finally, conclusions and recommendations are provided.

\section{Methodology and Specimens}

In the presented experimental activity, the effect of perforations (openings) in the infill walls on the lateral strength and stiffness of $(\mathrm{RC})$ frames was carried out. For this purpose, typical reinforced concrete full-scale frames were tested under in-plane lateral loading. Two full-scale one-storey, one-bay RC frames having openings at different positions were fabricated. The infill wall of one RC frame was constructed having window while the other infilled frame was provided with both door and window. Each infilled frame was constructed on a RC pad having $3.7 \times 0.61 \times 0.35 \mathrm{~m}$ $(12 \times 2 \times 1 \mathrm{ft})$ dimensions. The dimensions of both beam and columns were $0.30 \times 0.30 \mathrm{~m}(1 \times 1 \mathrm{ft})$. The flow chart of the methodology is shown in Figure 1.

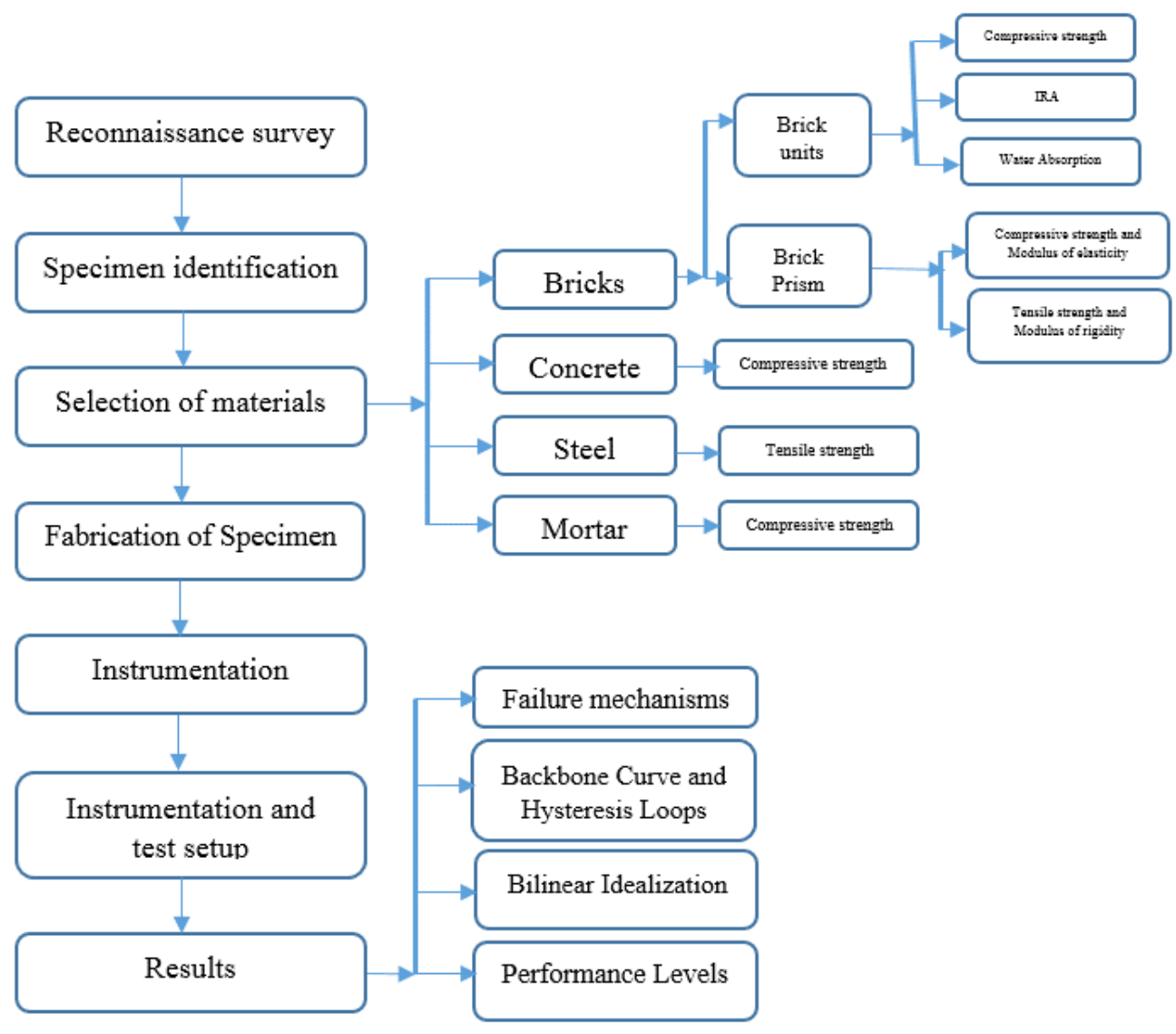

Figure 1. Flow chart of the methodology 
A reinforced concrete pad was fixed to the floor using $25 \mathrm{~mm}$ (1 inch) diameter anchors to prevent uplifting of the wall during testing. The infill wall was built in English bond pattern having a thickness of $228.6 \mathrm{~mm}$ (9 inches). The elevation detail and infilled frame model with window and door opening constructed in the laboratory are shown in Figure 2.

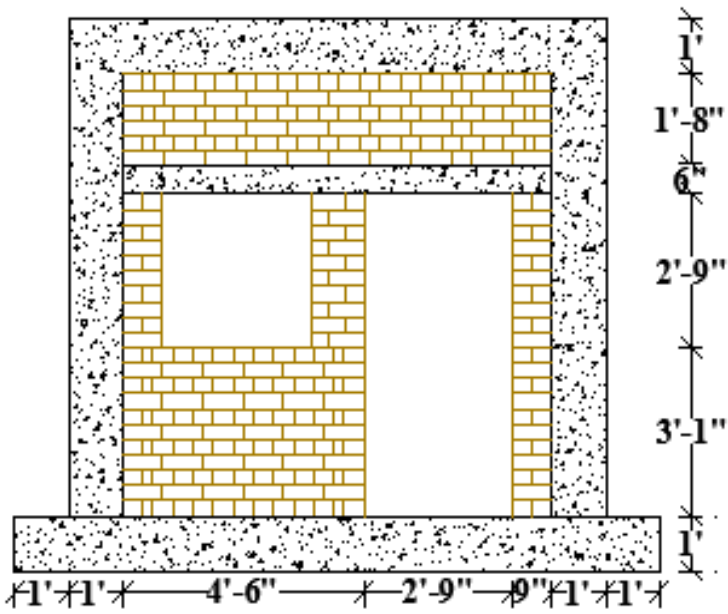

(a)

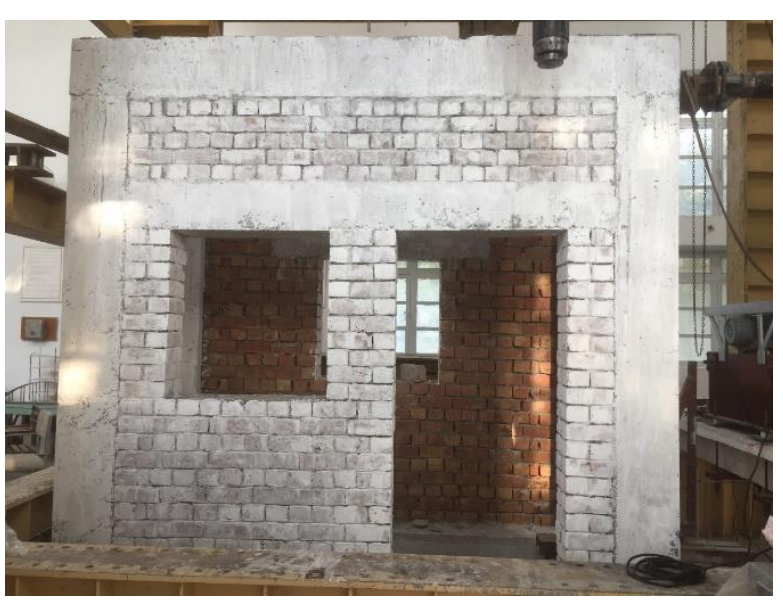

(b)

Figure 2. (a) Dimensions along Elevation of $\mathrm{RC}$ frame with infill after construction (b) Infilled frame having door and window opening $(1 \mathrm{inch}=25.4 \mathrm{~mm})$

Elevation details and actual model after the construction of the window opening constructed in the laboratory is shown in Figure 3.

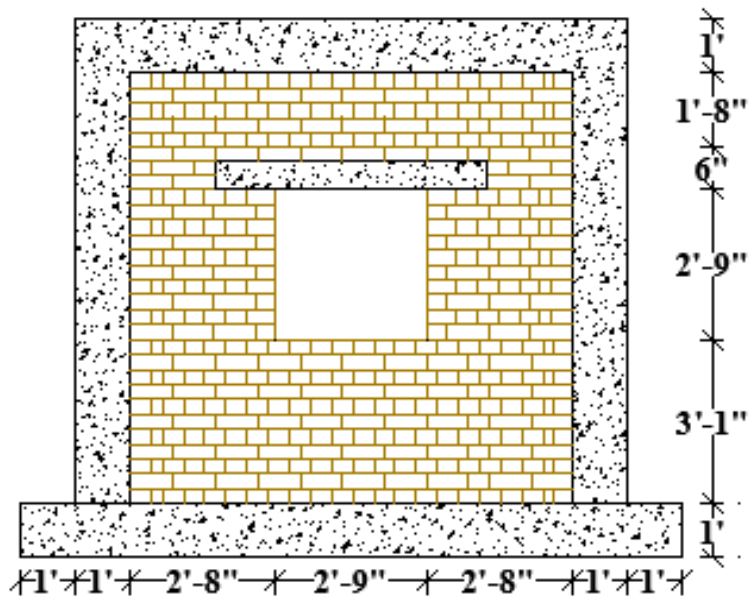

(a)

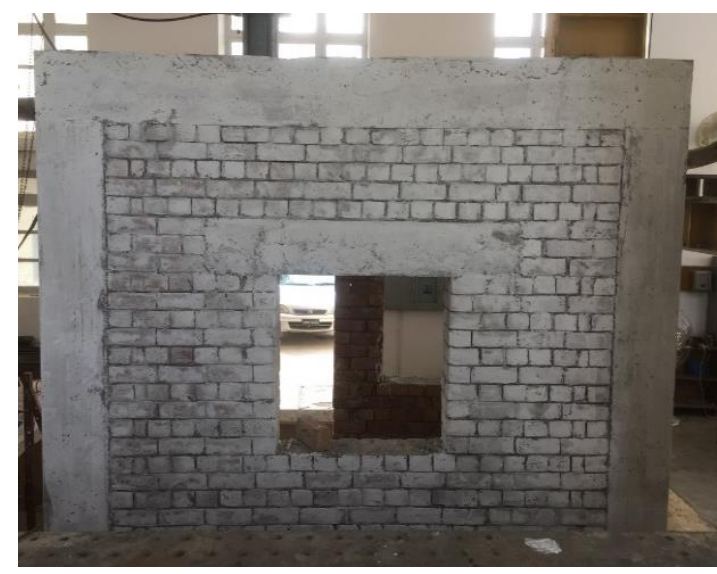

(b)

Figure 3. (a) Dimensions along Elevation of RC frame with infill (b) Infilled RC frame having only window opening $(1$ inch $=25.4 \mathrm{~mm})$

The section of the frame is shown in Figure 4 with the details of the section AA, section BB and section CC in Figure 5. Reinforcement detail of RC foundation is shown in Figure 6. 


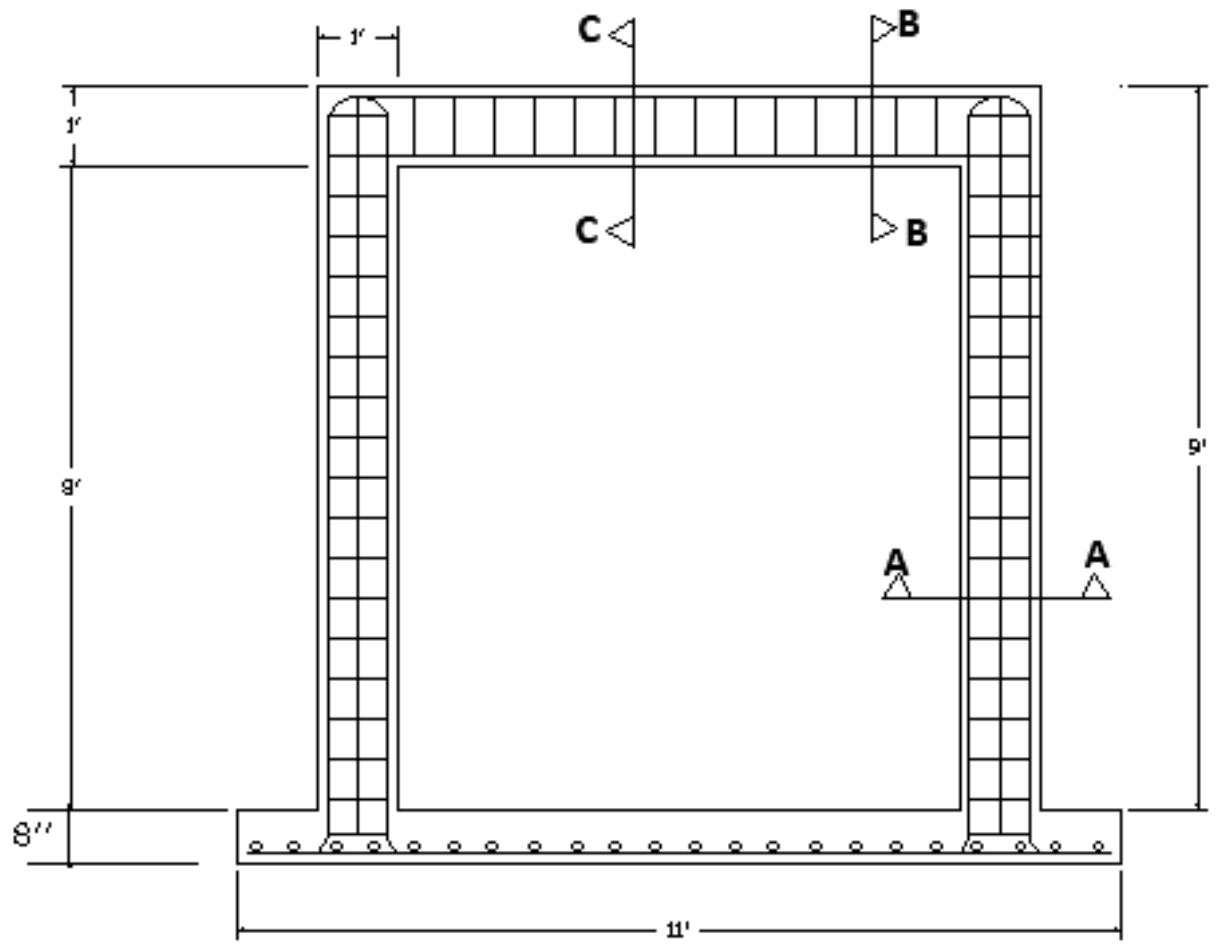

Figure 4. Reinforcement Details of bare frame $(1 \mathrm{inch}=25.4 \mathrm{~mm})$

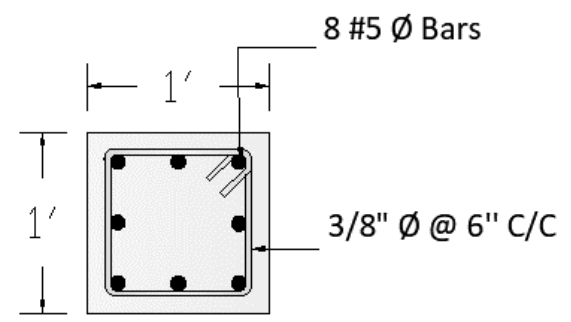

SECTION A-A

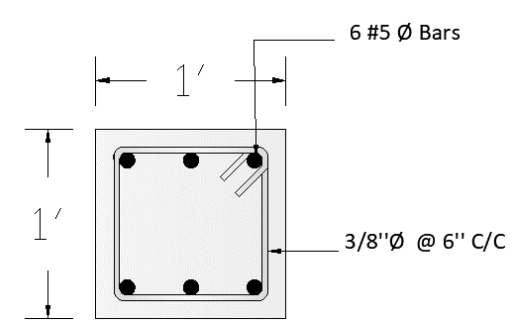

SECTION B-B

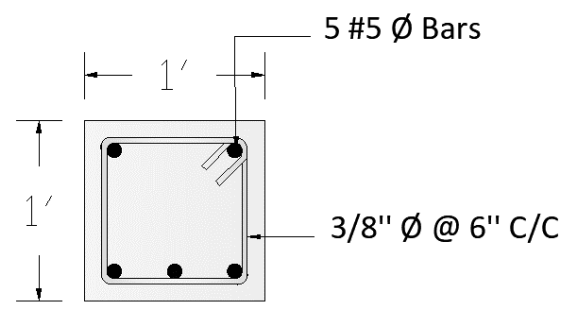

SECTION C-C

Figure 5. Reinforcement Detail of Sections $(1 \mathrm{inch}=25.4 \mathrm{~mm})$

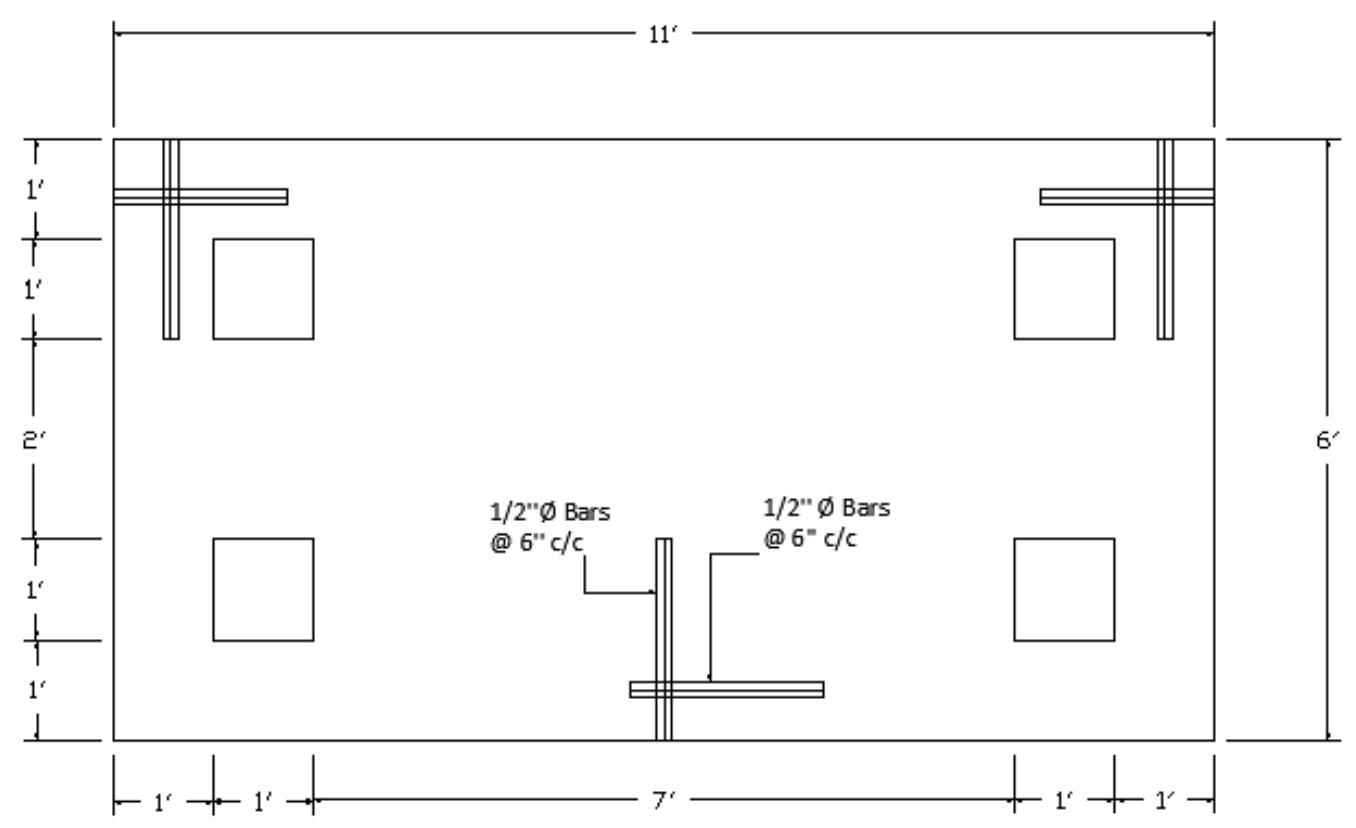

Figure 6. $\mathrm{RC}$ foundation pad $(1 \mathrm{inch}=25.4 \mathrm{~mm})$ 


\section{Material Properties}

This section consists of the material collection that has been required for construction of the infill wall. One of the primary materials of this research work was brick. Therefore, after conducting various tests on bricks, first-class brick from locally available resource was selected. The reinforcement selected was of grade 40, having a yield strength of $276 \mathrm{MPa}$ (40ksi). Type-1 cement from the local cement factory, i.e. Kohat factory of cement was used as a binding material. The coarse aggregate from Basai quarry was selected because of its irregular shape as it enhances the strength of standard excellent fineness modulus. ASTM C136 [22] was used for the sieve analysis, and the result of the sieve analysis of the coarse aggregate is shown in Figure 7. Similarly, ASTM C136 was used for the sieve analysis of the fine aggregate, which was collected from the Nizampur quarry; the result is shown in Figure 8. After collection of different material, the second phase of the research work was to conduct different tests on the material selected and to find out its properties, i.e. compressive strength, modulus of elasticity, diagonal compression and water absorption.

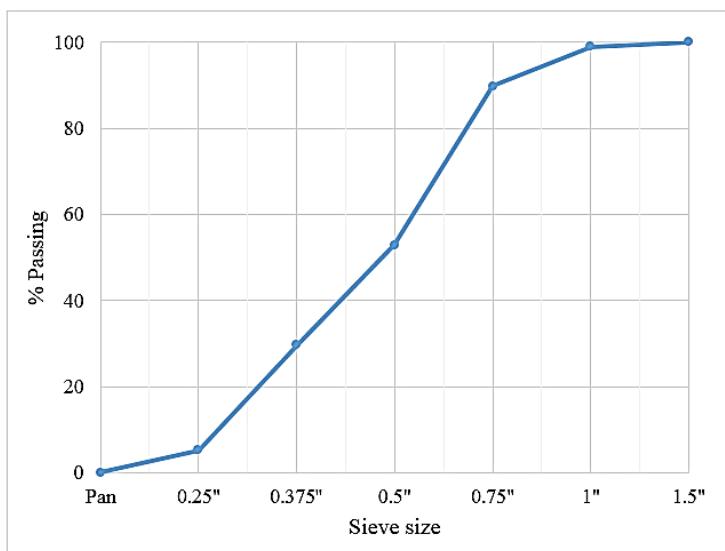

Figure 7. Sieve analysis of coarse aggregate

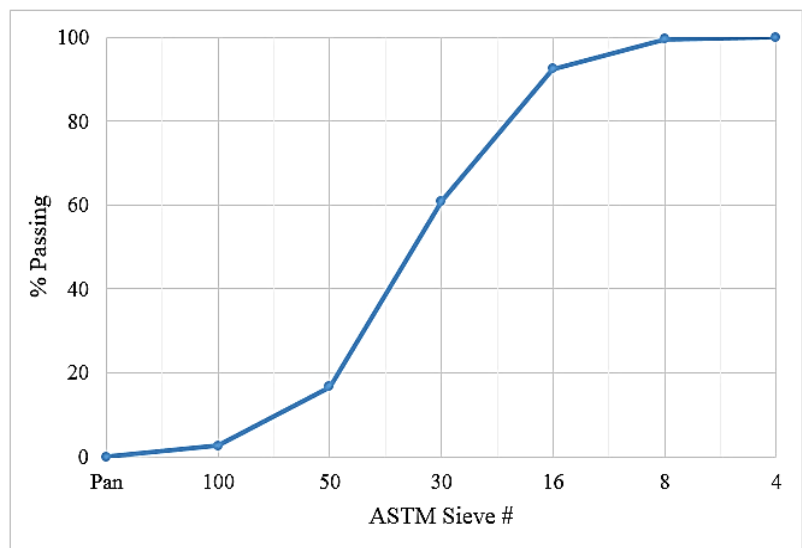

Figure 8. Sieve analysis of fine aggregate

ASTM C-109 specification [23] was used to find the compressive strength of mortar. The cement to the sand ratio of mortar consisted of one part of cement and six parts of sand with water to cement ratio of 0.50 . The mortar cubes were prepared in standard size moulds of $51 \times 51 \times 51 \mathrm{~mm}(2 \times 2 \times 2 \mathrm{in})$ and were removed from the moulds after 24 hours. The casted concrete cubes were placed in water for 28-days. The compressive strength of mortars was determined in Universal Testing Machine (UTM) after 28-days of curing. The tests performed in the laboratory to determine the properties of the material are summarized in Table 1.

Table 1. Material properties obtained from various tests

\begin{tabular}{cccc}
\hline Description & Symbols & Values & Units \\
\hline Yield strength of steel, & $\mathrm{f}_{\mathrm{y}}$ & $40(276)$ & $\mathrm{psi}(\mathrm{MPa})$ \\
Compressive strength of mortar, & $\mathrm{f}_{\mathrm{mo}}{ }^{\prime}$ & $1291(8.9)$ & $\mathrm{psi}(\mathrm{MPa})$ \\
Compressive strength of masonry, & $\mathrm{f}_{\mathrm{m}}{ }^{\prime}$ & $960(6.6)$ & $\mathrm{psi}(\mathrm{MPa})$ \\
Elastic modulus of masonry, & $\mathrm{E}_{\mathrm{m}}$ & $198.6(1370)$ & $\mathrm{ksi}(\mathrm{MPa})$ \\
Compressive strength of bricks, & $\mathrm{f}_{\mathrm{b}}$ & $1800(12.7)$ & $\mathrm{psi}(\mathrm{MPa})$ \\
Initial rate of absorption, & -- & 65 & $\mathrm{~g} / \mathrm{min} / 30 \mathrm{in}^{2}$ \\
Water absorption of bricks, & -- & 20 & $\%$ \\
Diagonal tensile strength of masonry, & $\mathrm{f}_{\mathrm{tu}}$ & $7.5(0.052)$ & $\mathrm{psi}(\mathrm{MPa})$ \\
Modulus of rigidity of masonry & $\mathrm{G}_{\mathrm{m}}$ & $4.49(30.96)$ & $\mathrm{ksi}(\mathrm{MPa})$ \\
Compressive strength of concrete, & $\mathrm{fc}^{\prime}$ & $3023(20.84)$ & $\mathrm{pcf}(\mathrm{MPa})$ \\
\hline
\end{tabular}

The compressive strength of masonry prisms was determined according to ASTM C-1314 [24]. The dimensions of the prepared masonry prism were $406 \mathrm{~mm}$ (16 inches) high, $406 \mathrm{~mm}$ (16 inches) length and a thickness of $229 \mathrm{~mm}(9$ inches). The masonry prism was prepared in English bond with $0.01 \mathrm{~m}$ (3/8 in) mortar joints. After that, the compressive strength of masonry prism was then determined by dividing peak failure load into areas of the loaded surface. The compressive strength of bricks prism came out to be $6.6 \mathrm{MPa}(960 \mathrm{psi})$. The stress-strain curve of the brick prism is shown in Figure 9. 


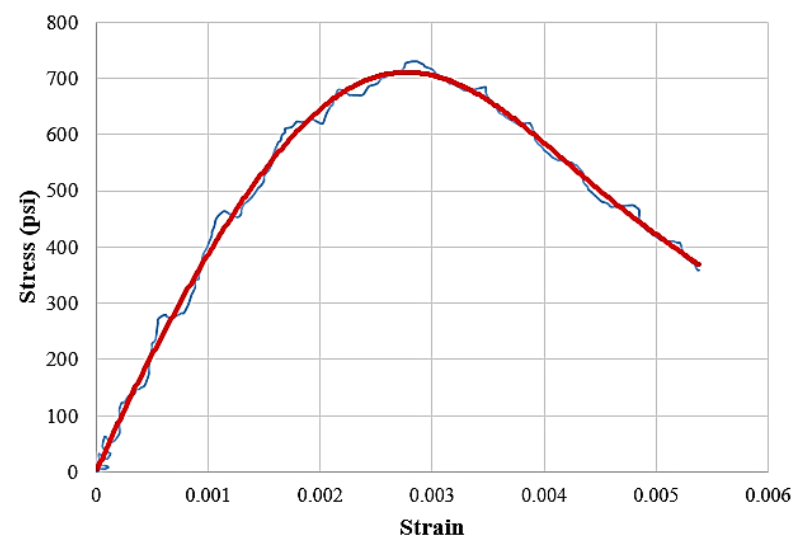

Figure 9. Stress-strain curve of masonry prism

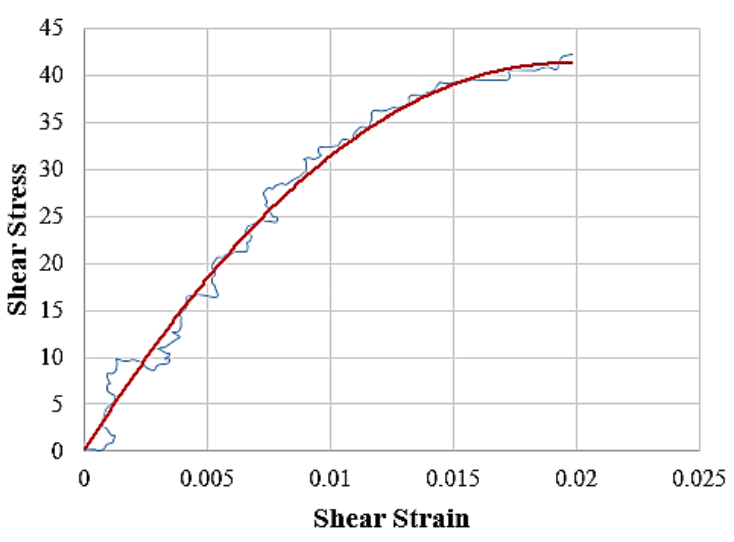

Figure 10. Shear stress versus shear strain curve of masonry prism

Modulus of elasticity (Em) was determined according to ASTM C-1314 specification. Two dial gauges were used to measure deformation in the specimen with applied uniaxial loading, Equation 1 provides modulus of elasticity of prism.

Modulus of elasticity $=($ longitudinally stress $) /($ longitudinally strain $)$

Similarly, masonry prisms were also tested in a diagonal direction to determine the shear strength and modulus of rigidity. The shear stress-strain curve of the brick prism is shown in Figure 10, and the modulus of rigidity was calculated from the shear stress-shear strain curve as the secant modulus between two points corresponding to $1 / 20$ and $1 / 3$ of peak shear strength. The compressive strength of bricks was determined by using ASTM standard specification C-67 [25]. Nine bricks were tested in Universal Testing Machine (UTM) under uniaxial loading. Before testing the bricks; steel plates were placed on top and bottom side of the brick so that the load is equally distributed. After testing the brick samples, the average compressive strength obtained was $12.7 \mathrm{MPa}(1.8 \mathrm{ksi})$. Initial rate of absorption of the brick unit was measured by adopting ASTM C-67 specification and was calculated by using Equation 2.

Initial rate of absorption $=((\mathrm{Ww}-\mathrm{Wd}) 30) / \mathrm{AC})\left(\mathrm{gm} / \mathrm{min} / 0.02 \mathrm{~m}^{2}\left(\mathrm{gm} / \mathrm{min} / 30 \mathrm{in}^{2}\right)\right)$

After performing the IRA on different samples, the average value IRA test was $65 \mathrm{~g} / \mathrm{min} / 0.019 \mathrm{~m}^{2}$ $\left(0.14 \mathrm{Ibs} / \mathrm{min} / 30 \mathrm{in}^{2}\right)$. Water absorption of bricks sample was determined by picking the oven-dried sample and was placed in water for 24 hours - the water absorption of bricks masonry determined by using Equation 3.

Absorption $(\%)=(\mathrm{Ww}-\mathrm{Wd}) / \mathrm{Wd} \times 100$

In the end, average water absorption value was recorded as $20 \%$. The diagonal tensile strength of bricks was determined according to ASTM E 519-02 [26]. Brick masonry prisms of dimension $0.41 \mathrm{~m}$ (16 inches) high, $0.41 \mathrm{~m}$ (16 inches) long and $0.23 \mathrm{~m}$ (9 inches) thick were subjected to tests. ASTM E 519-02 specification was used to determine shear stress in brick masonry prism. Shear stress is determined by using Equation 4.

$\mathrm{SS}=(0.707 \mathrm{PD}) / \mathrm{An}$

RILEM specification was used to determine the tensile strength of prism from diagonal compression testing, [21]. As there are no ASTM, specification equation (5) is used to compute the tensile strength of brick masonry prism.

$\mathrm{ft} \mu=(0.5 \mathrm{P} \mu / \mathrm{An})$

The modulus of rigidity "Gm" was determined after plotting shear stress vs. shear strain curve. In the end, the tensile strength of bricks masonry was $51.71 \mathrm{kPa}(7.5 \mathrm{psi})$. The compression strength of the concrete cylinder was determined by adopting ASTM C-39 [27] specification. Concrete cylinders were prepared in 1:2:4 mix proportion with water to binder ratio of 0.45 . Before testing, the concrete surface was capped in gypsum. 


\section{Instrument Set-up}

Quasi-static loading has been used to determine the lateral stiffness of the RC frame structure. The quasi-static test is of two conditions i) Force controlled ii) Displacement controlled. In the displacement control test, the displacement is changed while in the force-controlled test, the force is under our control and is increased incrementally. Therefore, this method of testing is used to find the failure-mechanism of cracks and energy dissipation of structures. In this method, gauges are set up at pre-determined locations, and structural stiffness is continuously monitored. The arrangement of loading is shown in Figure 11.

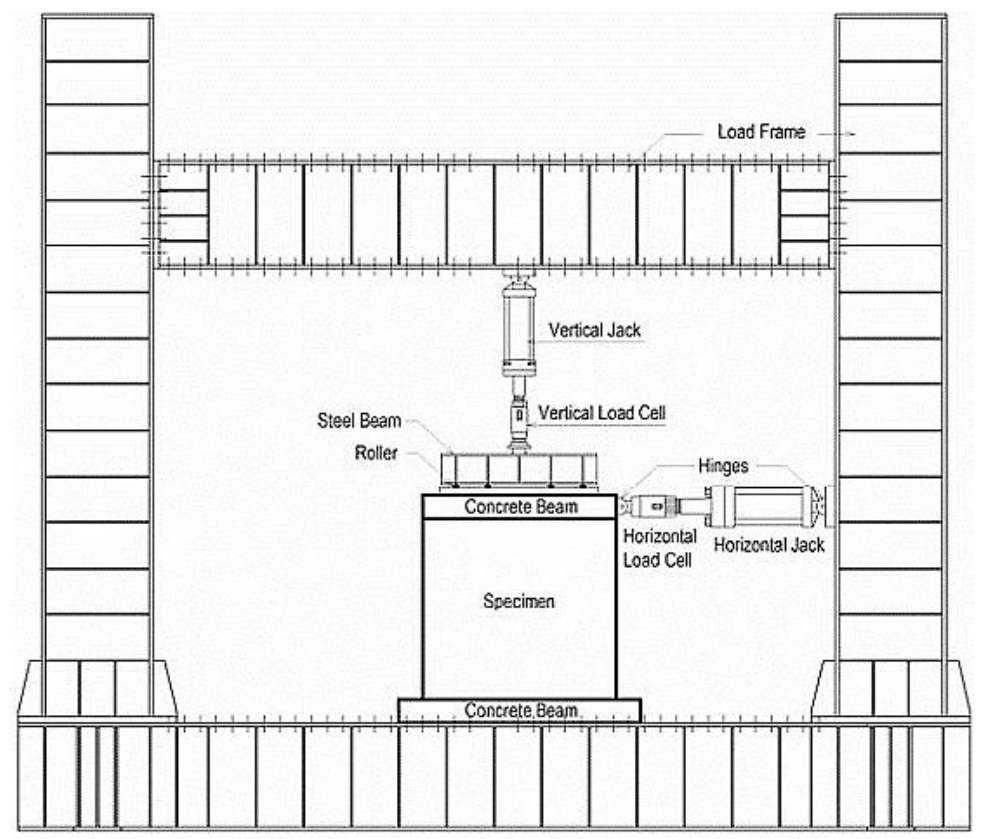

Figure 11. Schematic layout of loading

The test setup consists of two hydraulic jacks fixed with steel frame having zero deformation (strong frame). One jack applies vertical loads while the other applies horizontal loads. These jacks are controlled through hydraulic machines. In instrumentation, two load cells of 50tons capacity were incorporated to measure horizontal and vertical loads on structures. Table 3 is showing instrumentation layout of dial gauges incorporated in frames with door and window opening.

Table 2. Details of instrumentation layout of dial gauges incorporated in frames with door and window opening

\begin{tabular}{ccccc}
\hline S. No & Channel & ID No & Co-efficient & Position \\
\hline 1 & Lateral load cell 0 & Cell\# 02 & & Horizontally \\
2 & Control Displacement 1 & String pod & & Beam centre main gauge \\
3 & 2 & YT9471 & 2847-(1.7562-2) & CRRB \\
4 & 3 & YT9491 & $2965(1.6863-2)$ & CRLB \\
5 & 4 & YT9496 & $2727(1.7940-2)$ & R-Diagonal \\
6 & 5 & YT9504 & $2899(1.7247-2)$ & L-Diagonal \\
7 & 6 & YT9482 & $2750(1.8181-2)$ & CLRB \\
8 & 11 & YT9479 & $2843(1.7587-2)$ & CLLB \\
9 & 12 & YT9498 & & CRRT \\
10 & 13 & YT9472 & & CLRT \\
11 & 14 & YT9518 & & CLRT \\
12 & 15 & YT9480 & & CLLB \\
13 & 16 & YT9477 & & CLRB \\
14 & 17 & YT9486 & & BRB \\
15 & 18 & YT9483 & & BLT \\
16 & 19 & YT9495 & BLB \\
17 & 20 & YR8690075 & BRT \\
18 & 21 & Load Cell & Horizontal-Opposite direction \\
19 & 22 & Cell\# 01 & Vertical \\
\hline
\end{tabular}


Figure 12 shows location and designation of dial gauges incorporated in frame with door and window opening. Moreover, Table 3 shows instrumentation layout of dial gauge incorporated in frame with window opening. Figure 13 shows the location and designation of dial gauges used in frame with window opening.

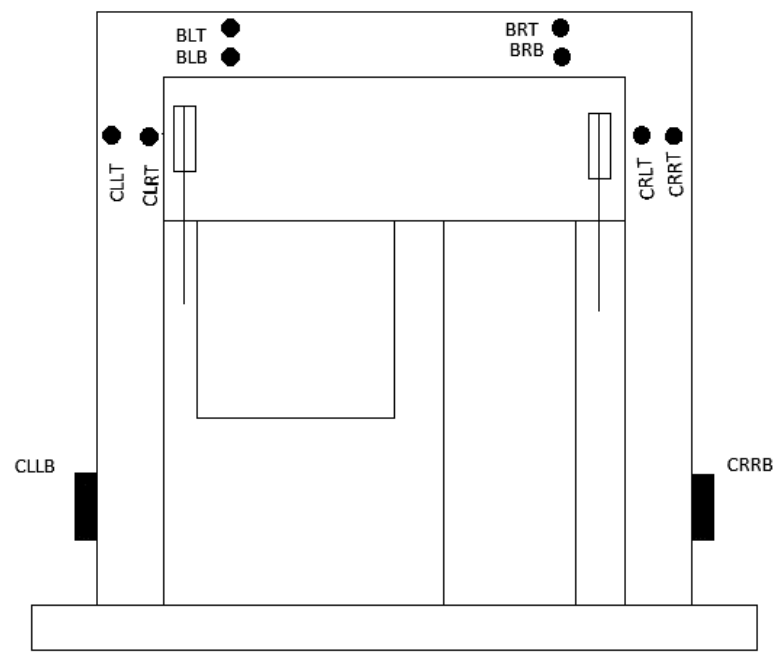

Figure 12. Instrumentation layout of $\mathrm{RC}$ frame infilled wall with door and window opening

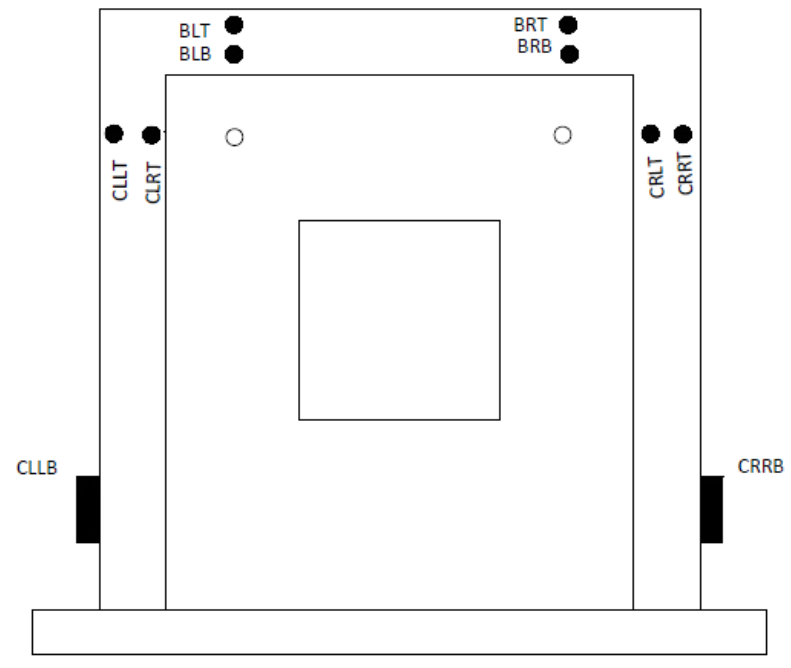

Figure 13. Instrumentation layout of RCC frame infilled wall with a window opening

Table 3. Details of instrumentation layout of dial gauge incorporated in frame with a window opening

\begin{tabular}{ccccc}
\hline S. No & Channel & ID No & Co-efficient & Position \\
\hline 1 & Lateral load cell 0 & Cell\# 02 & & Horizontally \\
2 & Control Displacement 1 & String pod & & Beam centre main gauge \\
3 & 2 & YT9471 & $2847-(1.7562-2)$ & CRRB \\
4 & 3 & YT9491 & $2965(1.6863-2)$ & CRLB \\
5 & 4 & YT9496 & $2727(1.7940-2)$ & R-Diagonal \\
6 & 5 & YT9504 & 2899(1.7247-2) & L-Diagonal \\
7 & 6 & YT9482 & $2750(1.8181-2)$ & CLRB \\
8 & 11 & YT9479 & $2843(1.7587-2)$ & CLLB \\
9 & 12 & YT9498 & & CRRT \\
10 & 13 & YT9472 & CLRT \\
11 & 14 & YT9518 & & CLRT \\
12 & 15 & YT9480 & & CLLB \\
13 & 16 & YT9477 & & CLRB \\
14 & 17 & YT9486 & & BRB \\
15 & 18 & YT9483 & BLT \\
16 & 19 & YT9495 & BLB \\
17 & 20 & YR8690075 & BRT \\
18 & 21 & Load Cell & Horizontal-Opposite direction \\
19 & 22 & Cell\# 01 & Vertical \\
\hline & & &
\end{tabular}

Before application of vertical and horizontal loading on RC-frames, loading setup is shown in Figure 14 for specimen-1. Moreover, loading setup is shown in Figure 15 for specimen-2. The displacement test protocol has been shown in Figure 16. 


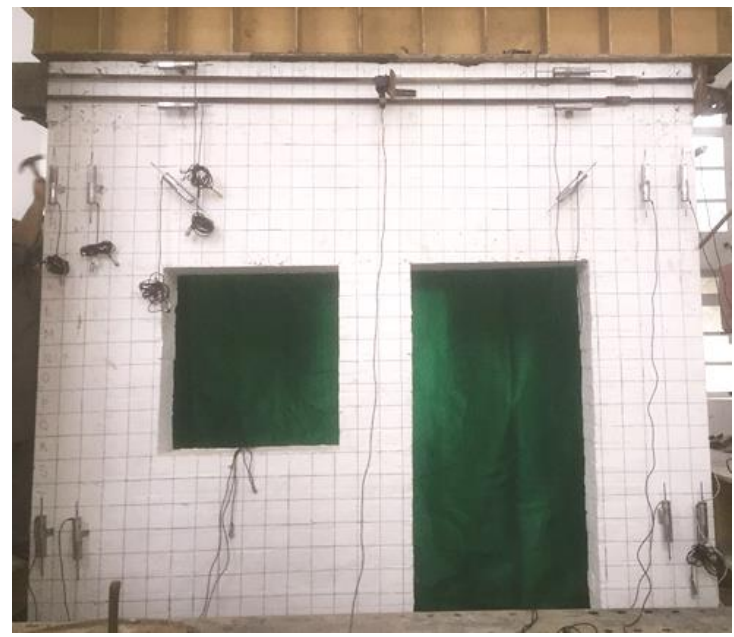

Figure 14: Instrumentation of the tested Specimen 1 model (Infilled frame with door and window opening)

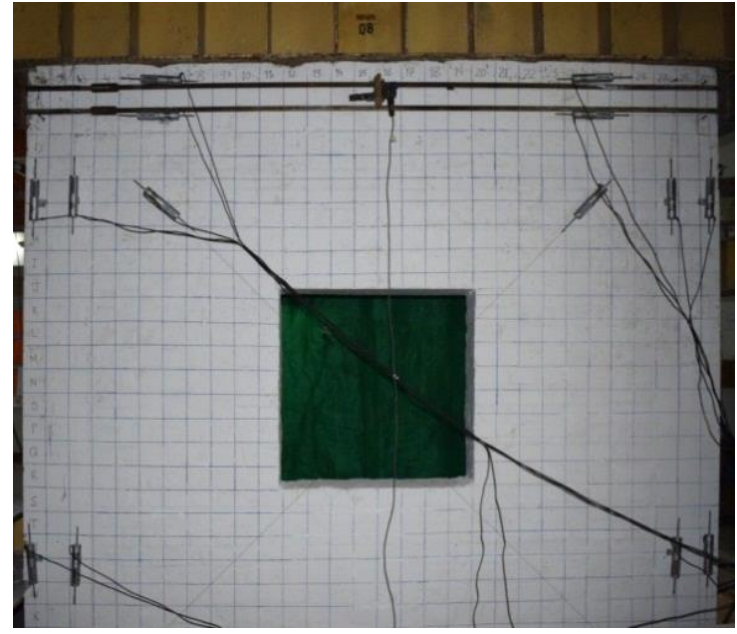

Figure 15: Instrumentation of the Specimen 2 model (Infilled frame with only window opening)

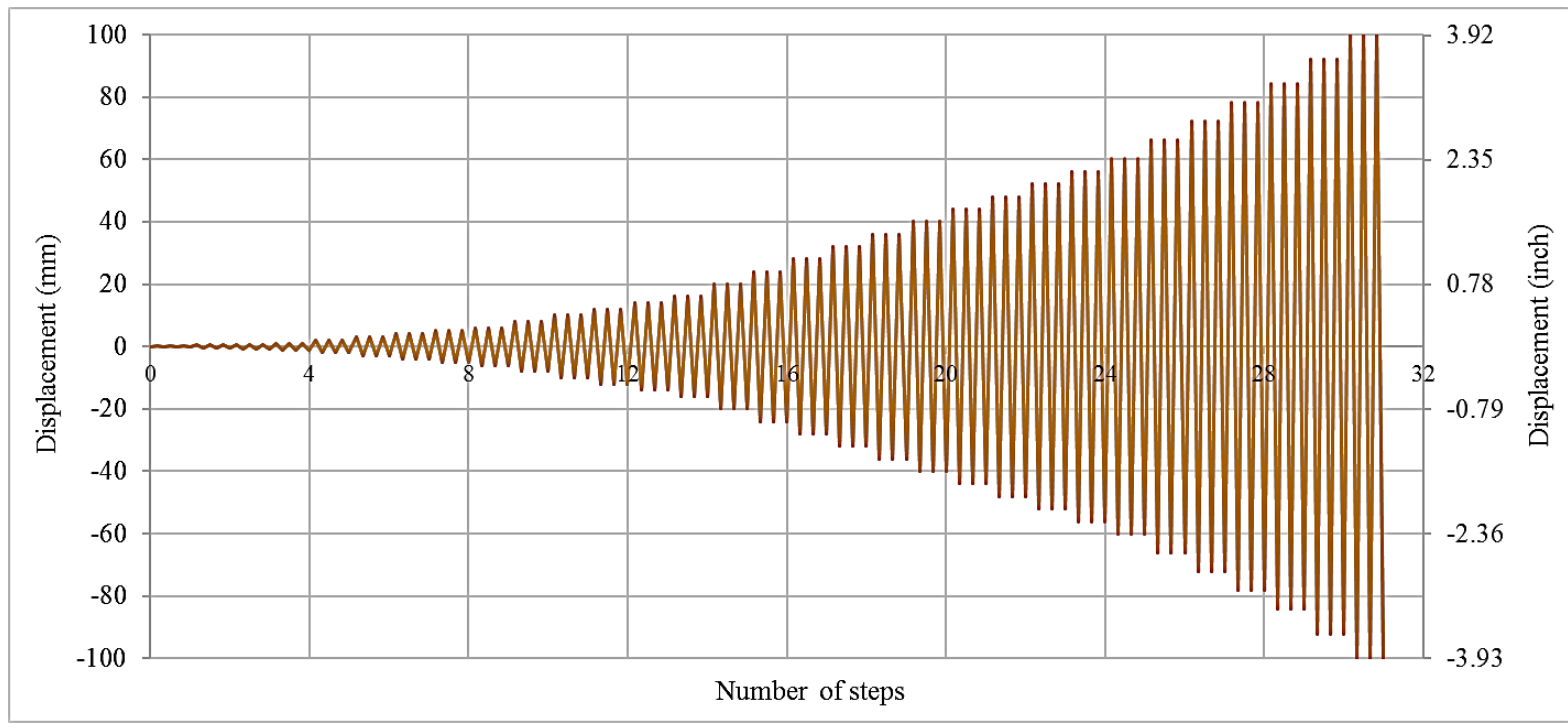

Figure 16. Test displacement protocol of the specimens

For both specimens, the same loading procedure was adopted, which consist of an increasing amount of in-plane quasi-static loading cycles in reverse nature. Eight (8) tons of pre-compressive loading was applied on both frames. Displacement cycle consists of loading the structure to a displacement of the desired amount. The load was removed after achieving the desired level of displacement in structure. After unloading, reloading stage was started to the same range of specified displacement. The crack that appears due to loading and unloading was adequately monitored and recorded. The models were laterally loaded with increments until the maximum capacity of RC frames was consumed.

\section{Failure Mechanisms}

\subsection{Failure-Mechanism of Specimen 1}

The results obtained from the experimental data are deliberated. The mechanism of cracks in each displacement cycle is also discussed. The quasi-static test for specimen-1 was started from $0.25 \mathrm{~mm}(0.01 \mathrm{inch})$ displacement cycle and ended on $100 \mathrm{~mm}$ (3.9 inch). Each displacement cycle was inspected for cracks mechanism. The FailureMechanism of cracks from $0.25-1.0 \mathrm{~mm}$ (0.01-0.04 inch) displacement cycle was the first recorded cycle, i.e. up to $1 \mathrm{~mm}$ and no cracks appeared in both the infill wall as well as in the RC frame. This shows that the structure can withstand the external loads under the above-applied displacement and loading conditions. At a $2 \mathrm{~mm}(0.078 \mathrm{inches})$ displacement cycle, a vertical crack appeared at the left side of the column wall joint, (See Figure17-a). At 4 mm (0.16 inch) displacement cycle, diagonal cracks were originated from the window corners at the sill-level, as shown in Figure17-b. A horizontal crack at the centre pier was seen due to bed joint sliding. A vertical crack also appeared at the right wall-column joint. At $6 \mathrm{~mm}(0.24 \mathrm{inch})$ displacement cycle diagonal crack was seen at the right pier of the door corner below the lintel beam (refer Figure 17-c). A horizontal crack below the centre pier was also noticed in this 
cycle. In this cycle, new cracks did not appear, but a small shear crack was seen at the right corner. The already appeared crack propagated is shown in Figure 17-d. At a displacement cycle of $10 \mathrm{~mm}(0.34$ inch $)$ sliding shear of mortar occurred at the top left side of the window (See Figure17-e). New cracks at the sill masonry appeared while pulling the structure. These cracks crossed the cracks formed in the previous cycle as depicted in Figure17-f. Since mid-pier has less area as compared to the other portions; therefore, stress concentration is enormous due to which cracks propagated in the central pier (refer Figure17-g).

Cracks appeared at a displacement cycle of $4 \mathrm{~mm}(0.157$ inches $)$ widen in this cycle as depicted in Figure 17-h. No new cracks appeared in this cycle, depicted in Figure17-i. In this cycle diagonal crack of the central pier and crack at the sill masonry were joined and the crack width was increased, depicted in Figure17-j. At a displacement cycle of 28 $\mathrm{mm}$ (1.1 inches) cracks were seen crossing each other at the sill masonry, depicted in Figure17-k. At $32 \mathrm{~mm}$ (1.26 inch) displacement cycle; sliding of the bed joint and diagonal shear cracks appeared at the spandrel masonry beside this width of the diagonal crack of the central pier was also increased, depicted in Figure17-1. No new cracks were seen at this cycle, depicted in Figure17-m. At this displacement cycle, spalling of the broken bricks from the central masonry pier occurred, depicted Figure17-n. At a displacement cycle of $48 \mathrm{~mm}$ (1.89 inches), the cracks become widen, and the central masonry pier was about to collapse, depicted in Figure17-o. In this cycle, the pier has taken loads to its full strength, and spalling of bricks from the central pier was observed, depicted in Figure 17-p.

After the collapse of the central pier, the load has been distributed to another uncracked part of the structure. Applied displacement and the corresponding cracks at displacement cycle of $60 \mathrm{~mm}$ (2.36 inch) (See Figure 11-q) several crossed diagonal cracks propagated at the spandrel masonry, as observed fromFigure11-r. At $84 \mathrm{~mm}$ cycle corner compression was observed (Figure17-s). No more cracks were observed, and the test was stopped at a displacement cycle of $100 \mathrm{~mm}$ (3.94 inch) (Figure17-t).

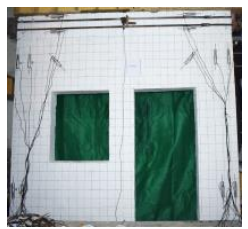

(a) $2 \mathrm{~mm}$

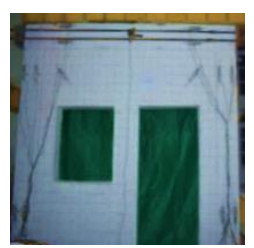

(f) $10 \mathrm{~mm}$

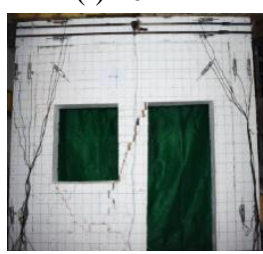

(k) $28 \mathrm{~mm}$

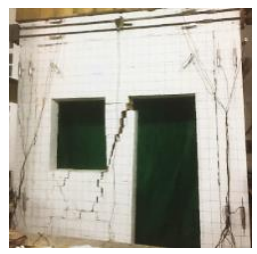

(p) $56 \mathrm{~mm}$

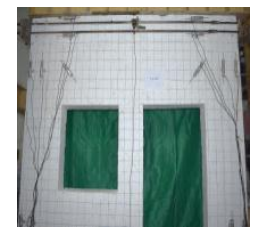

(b) $4 \mathrm{~mm}$

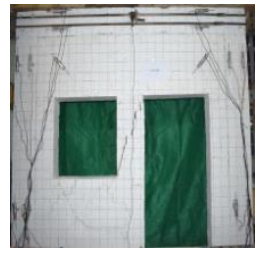

(g) $14 \mathrm{~mm}$

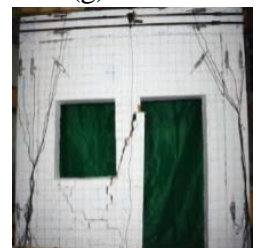

(1) $32 \mathrm{~mm}$

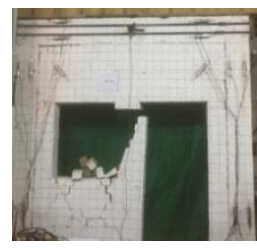

(q) $60 \mathrm{~mm}$

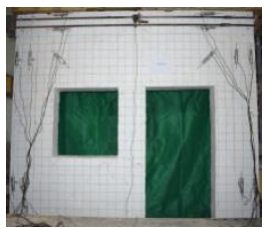

(c) $6 \mathrm{~mm}$

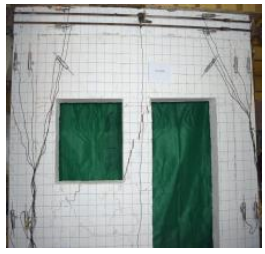

(h) $16 \mathrm{~mm}$

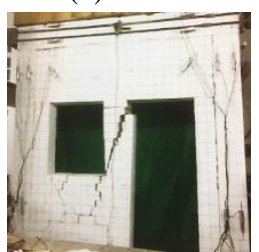

(m) $40 \mathrm{~mm}$

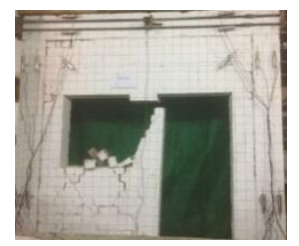

(r) $72 \mathrm{~mm}$

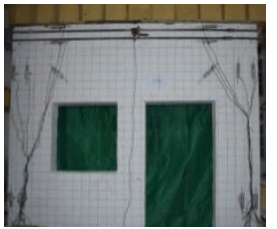

(d) $8 \mathrm{~mm}$

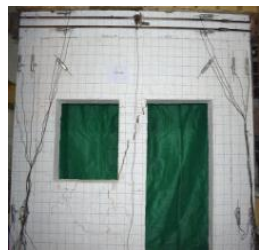

(i) $20 \mathrm{~mm}$

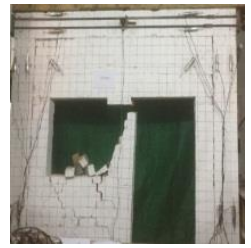

(n) $44 \mathrm{~mm}$

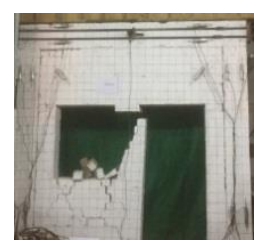

(s) $84 \mathrm{~mm}$

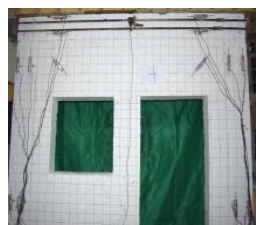

(e) $10 \mathrm{~mm}$

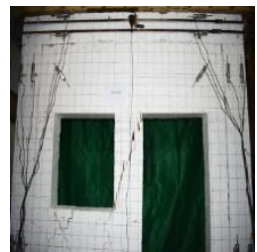

(j) $24 \mathrm{~mm}$

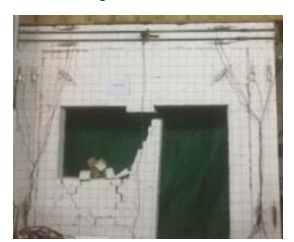

(o) $48 \mathrm{~mm}$

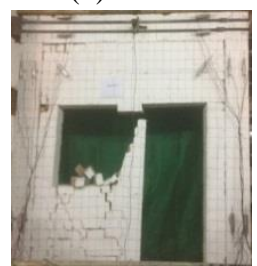

(t) $100 \mathrm{~mm}$

Figure 17. Applied displacements and the corresponding cracks in specimen-1 $(1$ inch $=25.4 \mathrm{~mm})$

\subsection{Backbone Curve and Hysteresis Loops of Specimen 1}

The Hysteresis loop and the capacity curve of the tested specimen 1 are shown in Figures 18 and 19, respectively. The maximum resistance of the structure was $137.73 \mathrm{kN}(30.96 \mathrm{Kip})$ at a drift of $1.42 \%$ and after the peak load degradation started. At $3.51 \%$ drift, peak load/strength was degraded by $28 \%$. Since the frame was degraded by more than $20 \%$ (collapse prevention) at this phase, therefore the test was terminated. 


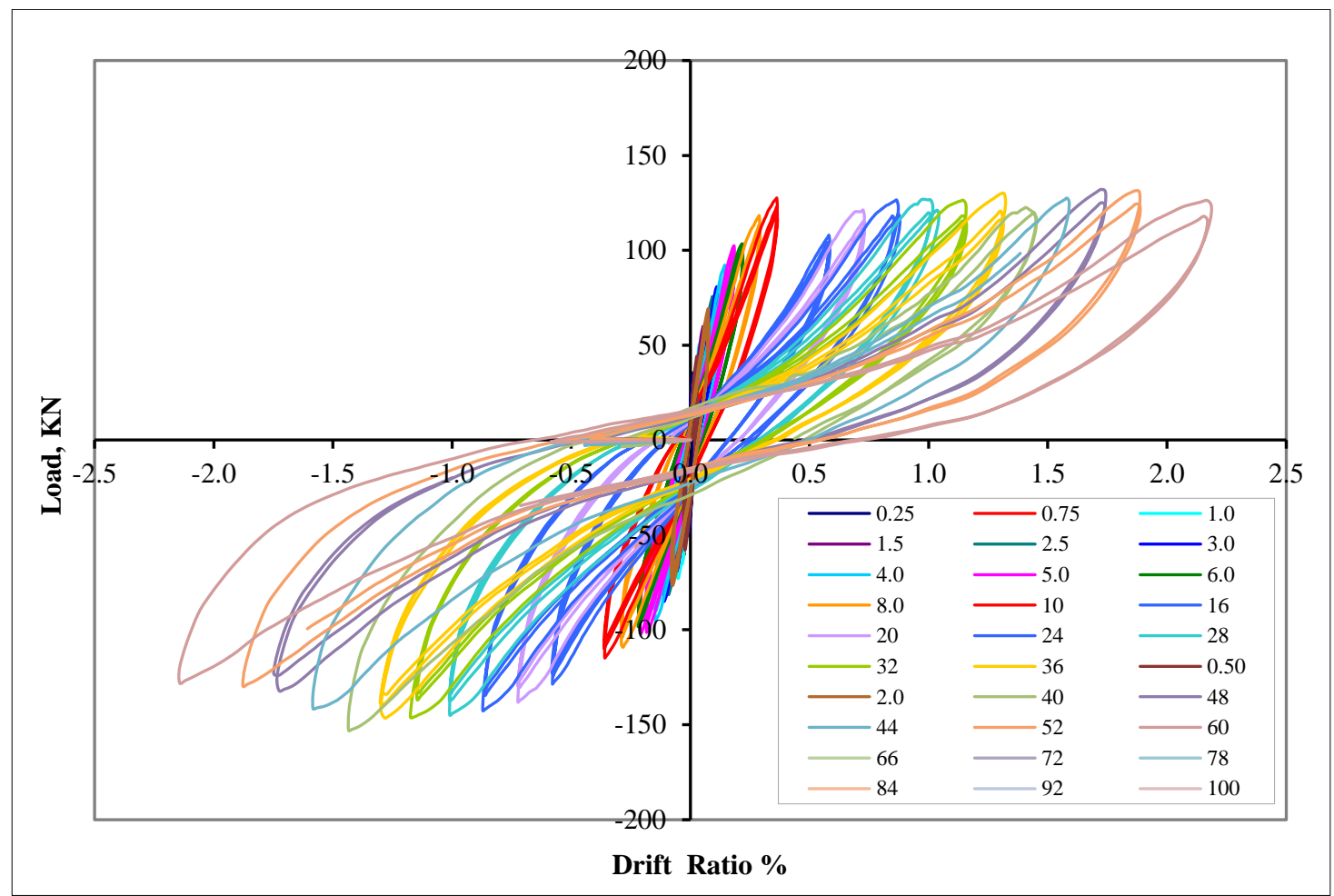

Figure 18. Force-deformation Hysteresis loops of Specimen-1

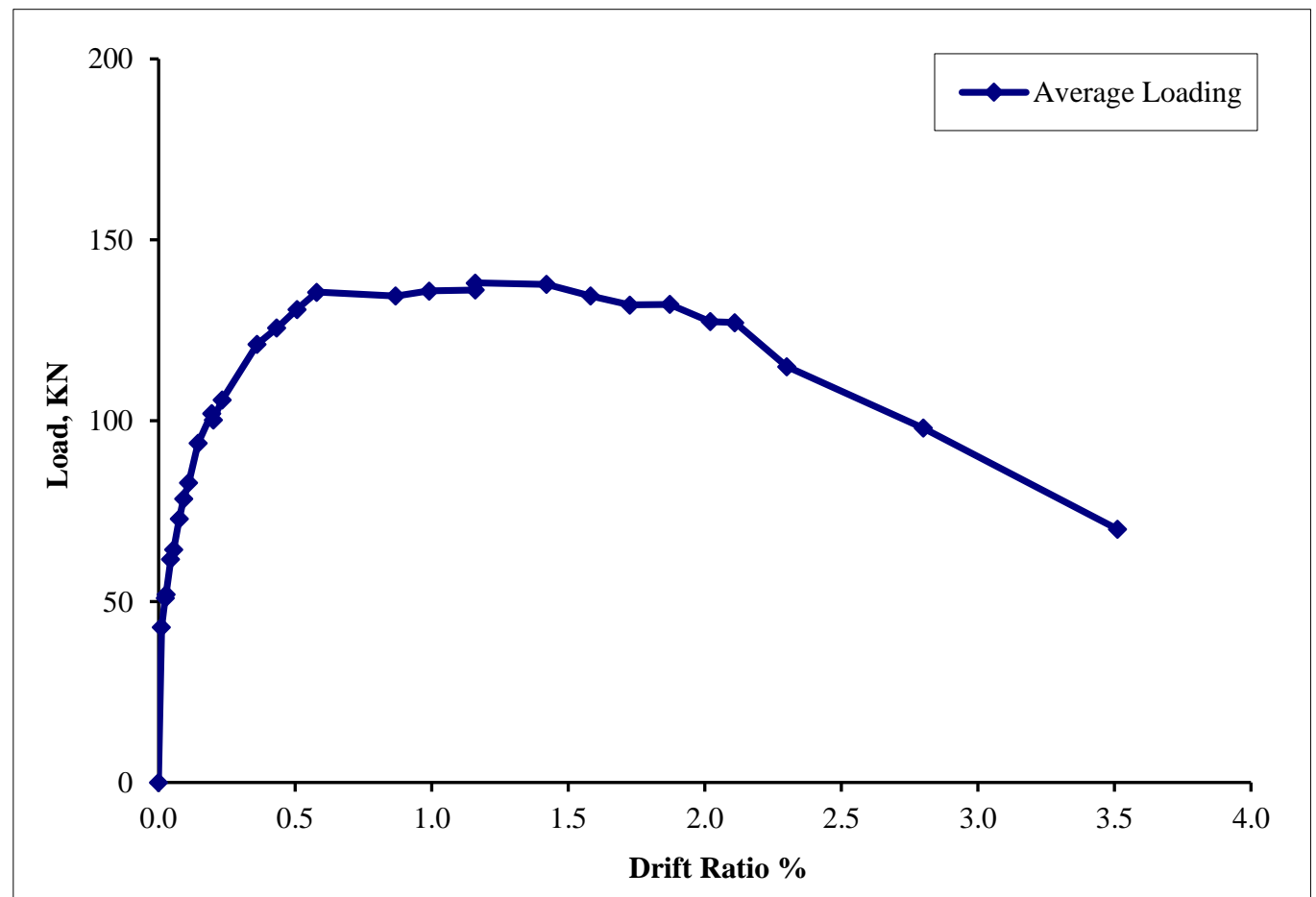

Figure 19. Capacity Curve for Specimen-1 $(1 \mathrm{inch}=25.4 \mathrm{~mm})$

Many researchers have used various curves to idealize the backbone curve; the model adopted for this work is shown in Figure 20 and used by Dehghani et al. (2015) [28], which is based on equal energy principle. The total resistance of the structure is $\mathrm{V}_{\max }$ according to the design proposed by Dehghani. Vs denote the point on the actual curve where the structural response dramatically deviates from the elastic response and where the first actual significant yield occurs. Ultimate displacement $\left(\Delta_{\mathrm{u}}\right)$ is the displacement point on the curve of the envelope corresponding to 80 per cent of the peak resistance, i.e. $0.8 \mathrm{Vmax}$. $\Delta_{\mathrm{y}}$ is the yield displacement on bilinear idealization curve and the load $\left(\mathrm{V}_{\mathrm{y}}\right)$ corresponding to yield displacement. The first line of the bilinear curve must intersect with the actual curve at a lateral force of $0.75 \mathrm{Vy}$ to obtain equivalent areas under the capacity and bilinear curve. The slope of the first line is the effective stiffness. Displacement ductility is the ratio of ultimate displacement to yield displacement $\left(\mu=\Delta_{\mathrm{u}} / \Delta_{\mathrm{y}}\right)$. 
$R_{s}$ is the over-strength factor, and the relationship was calculated by $R_{s}=V_{y} / V_{s}$. The structure's capacity for energy dissipation is represented by a reduction in ductility $\left(R_{\mu}\right)$ and was calculated by $R_{\mu}=\sqrt{(2 \mu-1)}$. The response modification factor $(R)$ was derived as $R=R_{s} \times R_{\mu}$ (product of over-strength factor and ductility).

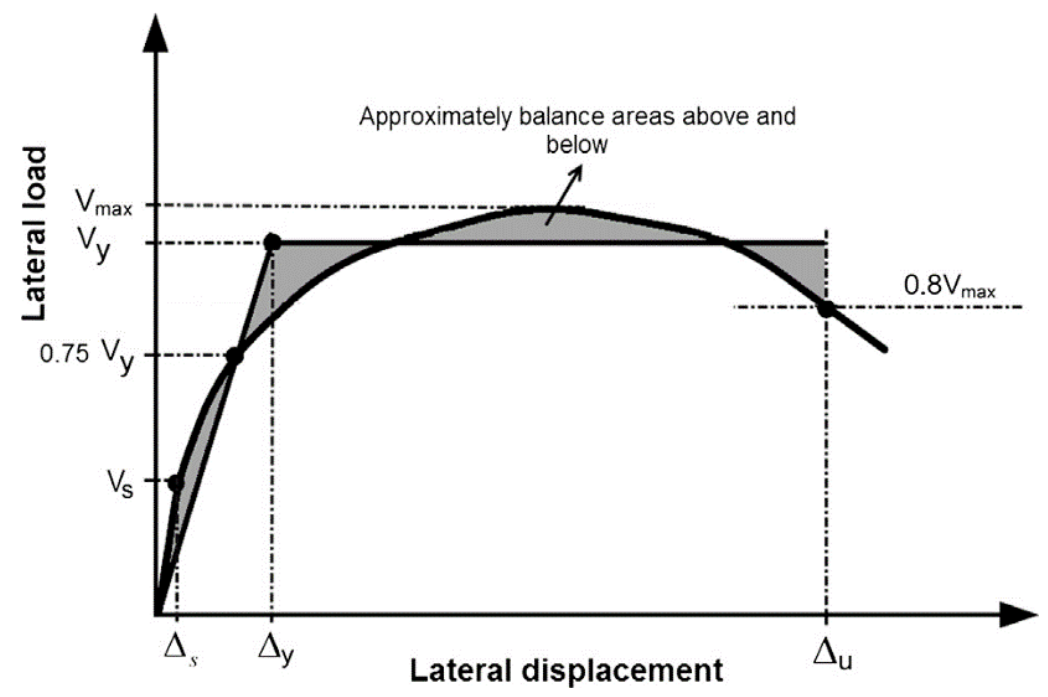

Figure 20. Idealized Bilinear Curve of the envelope

\subsection{Bi-linear Idealization Curve of Specimen 1}

Stiffness, Disp. Ductility and Response Modification Factor for specimen 1 are calculated from the bilinear and the obtained capacity curve, as shown in Figure 21. The yield Stiffness, Displacement ductility and Response Modification Factor for specimen 1 are shown in Table 4.

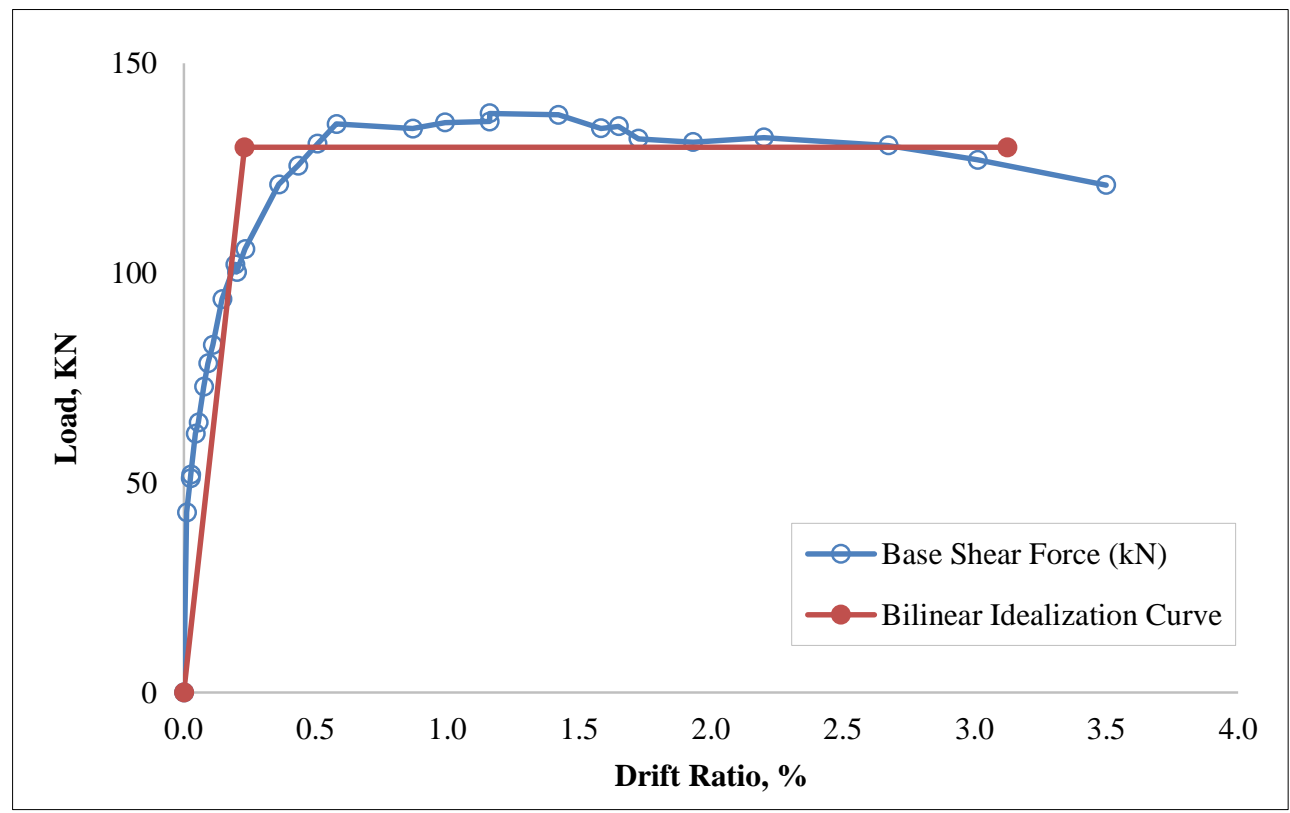

Figure 21. Idealized Bilinear and Capacity Curve of Specimen $1(1 \mathrm{inch}=25.4 \mathrm{~mm})$

Table 4. Stiffness, Displacement ductility and Response Modification Factor for specimen 1

\begin{tabular}{ccc}
\hline Yield Stiffness & $=\frac{0.9 \mathrm{Vmax}}{\mathrm{d} y}$ & $=14.99$ \\
\hline Ductility & $=\frac{\Delta \max }{\Delta y}$ & $=7.05$ \\
\hline $\mathrm{R} \mu$ & $=\sqrt{2 \mu-1}$ & $=3.62$ \\
\hline $\mathrm{Rs}$ & $=\mathrm{V}_{\mathrm{y}} / \mathrm{V}_{\mathrm{d}}$ & $=1.92$ \\
\hline $\mathrm{R}$ Factor & $=\mathrm{R}_{\mathrm{S}} \times \mathrm{R} \mu$ & $=6.95$ \\
\hline
\end{tabular}




\subsection{Failure-Mechanism of Specimen 2}

The test for frame 2 was started at $0.25 \mathrm{~mm}(0.01 \mathrm{inch})$ and ends at a displacement cycle of $60 \mathrm{~mm}(2.36 \mathrm{inch})$. Failure-Mechanism of cracks from $0.25 \mathrm{~mm}(0.01 \mathrm{inch})$ to $0.75 \mathrm{~mm}(0.029 \mathrm{inch})$. Testing of the specimen was started at a $0.25 \mathrm{~mm}(0.01 \mathrm{inch})$ cycle. Up to $0.50 \mathrm{~mm}(0.02 \mathrm{inch})$, the structure was strong enough to show resistance to external loadings due to which no cracks were observed. At $0.75 \mathrm{~mm}(0.029 \mathrm{inch})$ displacement cycle small diagonal crack appeared at the right masonry pier of the infill wall. Crack seen at $0.75 \mathrm{~mm}(0.029 \mathrm{inch})$ cycle extended towards the window corner in this cycle, depicted in Figure 22-a. Vertical crack a wall column joint was observed at the right masonry pier of the infill wall, depicted in Figure 22-c. At a displacement cycle of $4 \mathrm{~mm}$ (0.157 inches), diagonal cracks arise from each corner of the window, depicted in Figure 22-d. At 6 mm (0.23 inch) displacement cycle bond tensile failure occurred at the sill masonry, depicted in Figure 22-e. At $8 \mathrm{~mm}$ (0.31 inch) cycle sliding of beam-wall joint occurred, depicted in Figure 22-f. At $10 \mathrm{~mm}(0.39 \mathrm{inch})$ cycle, diagonal cracks were originated in the spandrel masonry, depicted in Figure 22-g. The Failure-Mechanism of cracks at $12 \mathrm{~mm}$ (0.47 inch) displacement cycle was such that bond shear failure at bed joints, bond tensile failure occurred at left and right of masonry piers, depicted in Figure 22-h.

In this displacement, several diagonal cracks were originated at the left masonry pier of the infill wall, depicted in Figure 22-i. The diagonal cracks that were originated in the previous cycles widen in this cycle, depicted in Figure 22j. A series of cracks originated were observed at the whole infill wall, i.e. spandrel masonry left and right masonry pier and at the sill masonry and is depicted in Figure 22-k. Spalling of mortar from the beam-wall joint and the cracks at the sill masonry widen, which is depicted in Figure 22-1. At a displacement cycle of $40 \mathrm{~mm}$ (1.57 inch), diagonal cracks at the left pier of the masonry were widened, and the crack width increases till a displacement cycle of $48 \mathrm{~mm}$ (1.89 inch). Diagonal crack width at the sill masonry increases in this cycle. At $60 \mathrm{~mm}$ (2.36 inch) displacement cycle corner compression at the top right and top left corner of the window occurred due to stress concentration. At the left masonry pier, masonry was separated due to crossing of the cracks, shown in Figure 22-q.

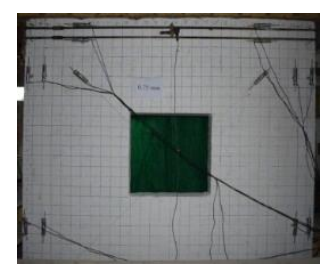

(a) $0.75 \mathrm{~mm}$

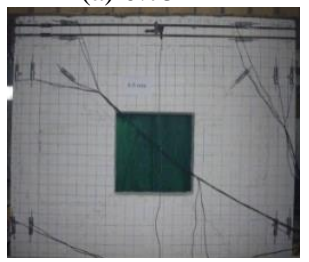

(e) $6.0 \mathrm{~mm}$

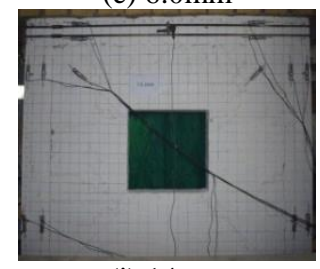

(i) $14 \mathrm{~mm}$

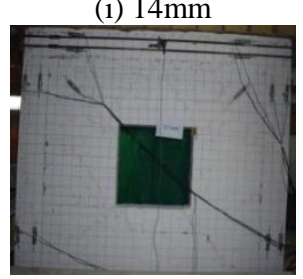

(m) $32 \mathrm{~mm}$

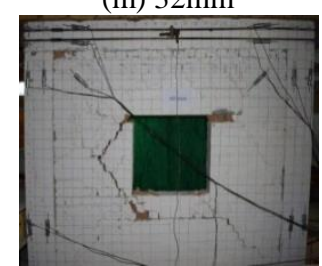

(q) $60 \mathrm{~mm}$

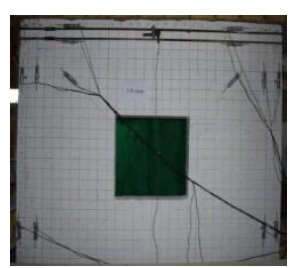

(b) $1.0 \mathrm{~mm}$

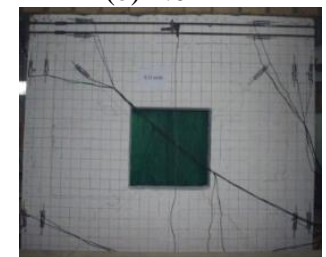

(f) $8.0 \mathrm{~mm}$

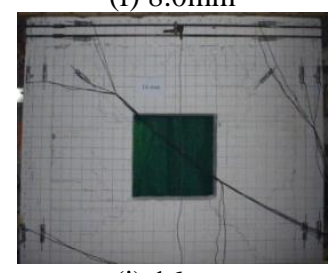

(j) $16 \mathrm{~mm}$

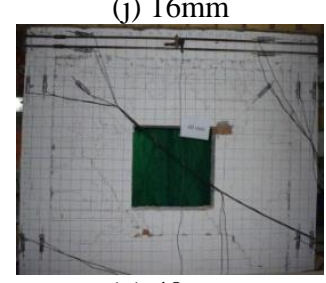

(n) $40 \mathrm{~mm}$

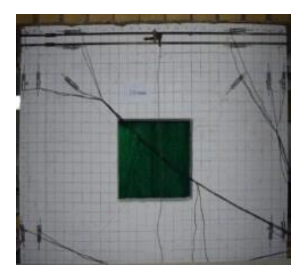

(c) $2.0 \mathrm{~mm}$

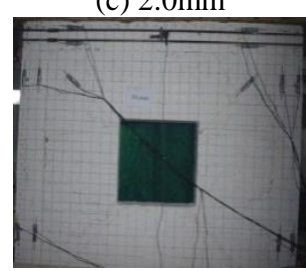

(g) $10 \mathrm{~mm}$

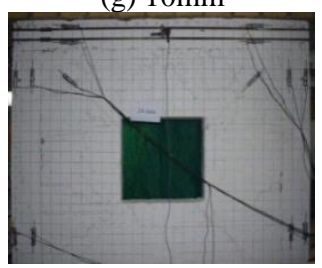

(k) $24 \mathrm{~mm}$

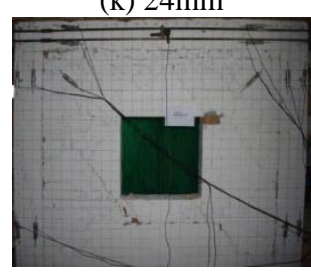

(o) $44 \mathrm{~mm}$

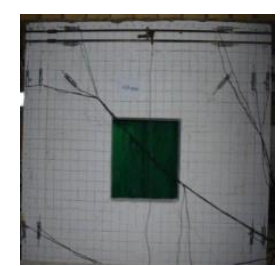

(d) $4.0 \mathrm{~mm}$

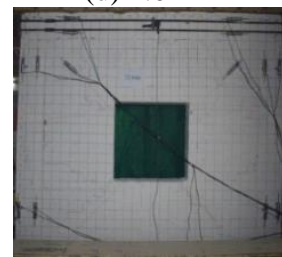

(h) $12 \mathrm{~mm}$

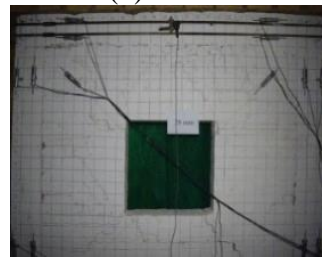

(1) $28 \mathrm{~mm}$

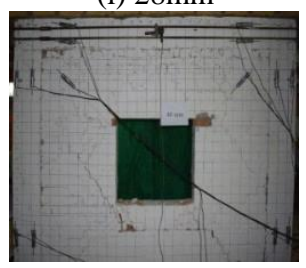

(p) $48 \mathrm{~mm}$

Figure 22. Applied displacements and the corresponding cracks in specimen-2 $(1 \mathrm{inch}=\mathbf{2 5 . 4} \mathrm{mm})$ 


\subsection{Backbone Curve and Hysteresis Loops of Specimen 2}

The Hysteresis loop and the capacity curve of the tested specimen 2 are shown in Figures 23 and 24, respectively. Specimen-1 resisted maximum load of $137.73 \mathrm{kN}(30.96 \mathrm{Kip})$ at a drift of $1.42 \%$ whereas specimen 2 resisted maximum load of $226.11 \mathrm{kN}(50.83 \mathrm{Kip})$ at a drift of $1.74 \%$, therefore strength was increased by $67 \%$ in the case of specimen-2 in which only window opening was provided instead of both door and window openings. Similarly, stiffness was also increased by $75 \%$ in the case of specimen- 2 .

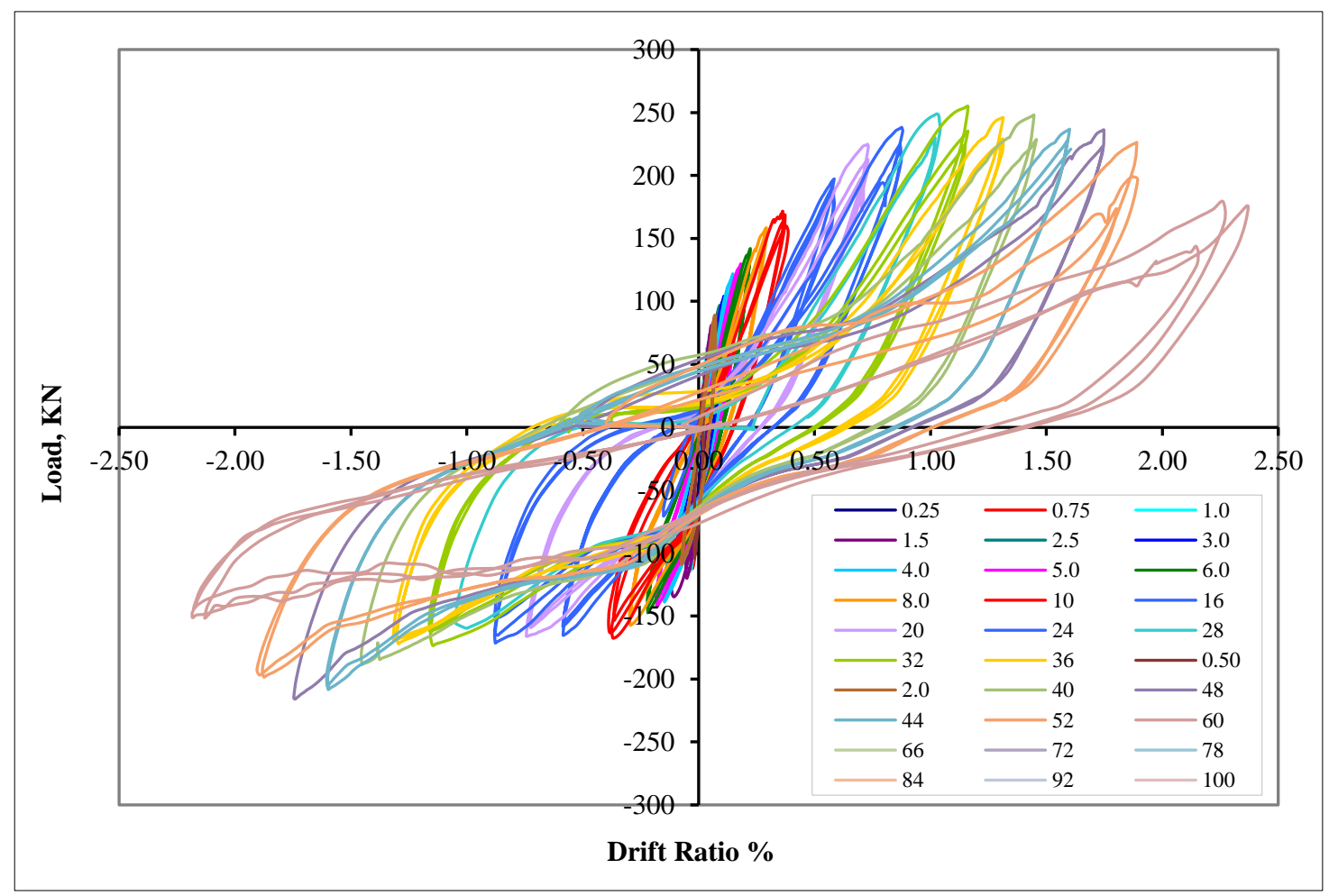

Figure 23. Hysteresis loops (Force-deformation) of Specimen 2

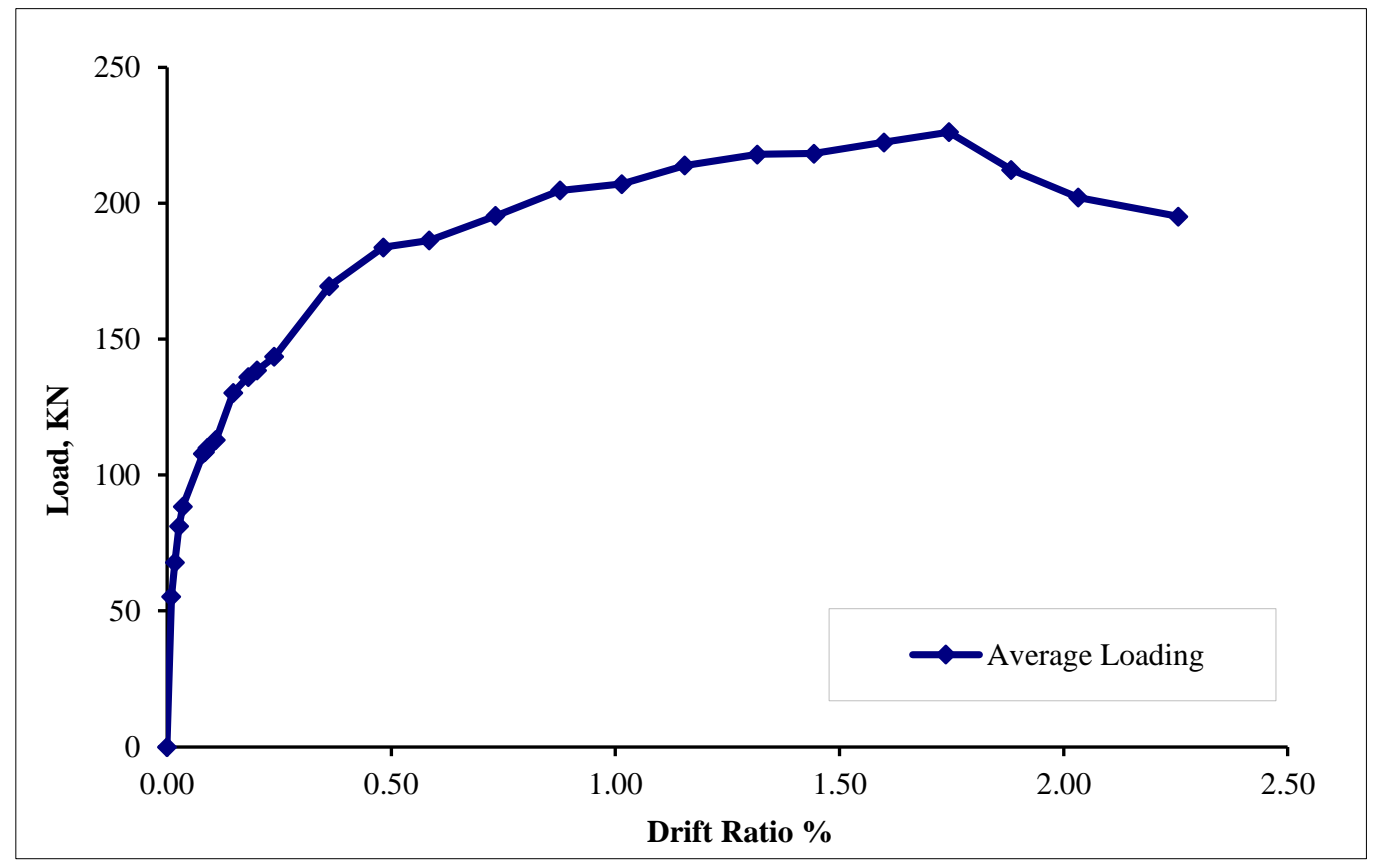

Figure 24. Capacity Curve for Specimen $2(1$ inch $=25.4 \mathrm{~mm})$

\subsection{Bilinear Idealization Curve of Specimen 2}

Stiffness, Disp. Ductility and Response Modification Factor for specimen-2 are calculated from the bilinear and the obtained capacity curve, as shown in Figure 25 . In the case of specimen-2 the openings increased ductility, by 
providing both door and window openings in the infilled frame instead of the only window opening, ductility increased by $14.04 \%$, it also increased the response modification factor of the frame. The yield Stiffness, Displacement ductility and Response Modification Factor for specimen-2 are shown in Table 5.

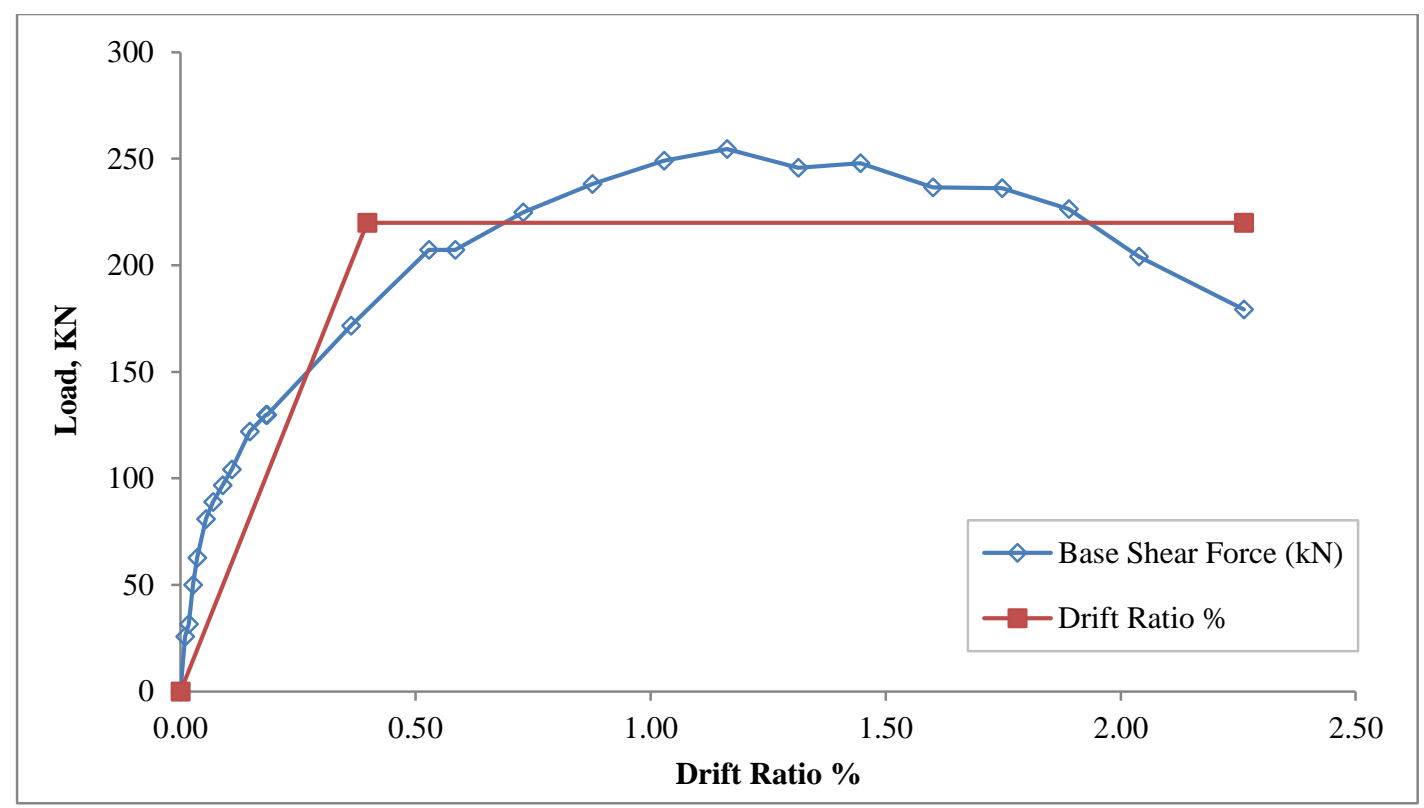

Figure 25. Bilinear Idealization Curve of Specimen $2(1$ inch $=25.4 \mathrm{~mm})$

Table 5. Stiffness, Displacement ductility and Response Modification Factor for specimen 2

\begin{tabular}{cc}
\hline Yield Stiffness & 15.25 \\
\hline Ductility & 6.06 \\
\hline $\mathrm{R} \mu$ & 3.33 \\
\hline $\mathrm{Rs}$ & 2.13 \\
\hline $\mathrm{R}$ Factor & 7.09 \\
\hline
\end{tabular}

Comparison of Seismic parameters for specimen-1 and specimen-2 are given in Table 6.

Table 6. Comparison of Seismic parameters of Specimen-1 and Specimen-2

\begin{tabular}{cccc}
\hline Description & Specimen-1 & Specimen-2 & $\begin{array}{c}\text { Ratio } \\
\text { (Specimen-2 / Speciemen-1) }\end{array}$ \\
\hline Lateral Load in kN (Kip) & $148.65(33.4)$ & $252.16(56.6)$ & 1.69 \\
$\mathrm{~K}_{\text {eff }}$ in KN/mm (pound/inch) & $0.40(2284)$ & $0.77(4396)$ & 1.93 \\
Ductility Factor $(\mu)$ & 7.05 & 6.06 & 0.85 \\
Ductility Reduction Factor, $\mathrm{R} \mu=\sqrt{\mathbf{2 \mu - \mathbf { 1 }}}$ & 3.62 & 3.33 & 0.91 \\
Over strength Factor $(\mathrm{Rs})$ & 1.92 & 2.13 & 1.10 \\
Force Reduction Factor, $\mathrm{R}=\mathrm{R} \mu \times \Omega$ & 6.95 & 7.09 & 1.02 \\
\hline
\end{tabular}

\section{Performance Levels}

There are three performance levels, according to ASCE/SEI 41-17 [29], Immediate Occupancy Level (IO); IO is the point on the backbone curve corresponding to yield drift. Yield drift was determined by $0.9 \mathrm{~V}_{\max }$ divide by $\mathrm{dy}=0.9 \mathrm{~V}_{\max } / \mathrm{dy}$.

Life Safety Performance Level (LS); LS are the point on backbone curve corresponding 0.75 of ultimate drift. Collapse Prevention Level (CP); CP is the point on the backbone curve corresponding to $20 \%$. The decrease in the lateral strength. The performance levels of the RC frame with Specimen-1 are depicted in Figure 26. 


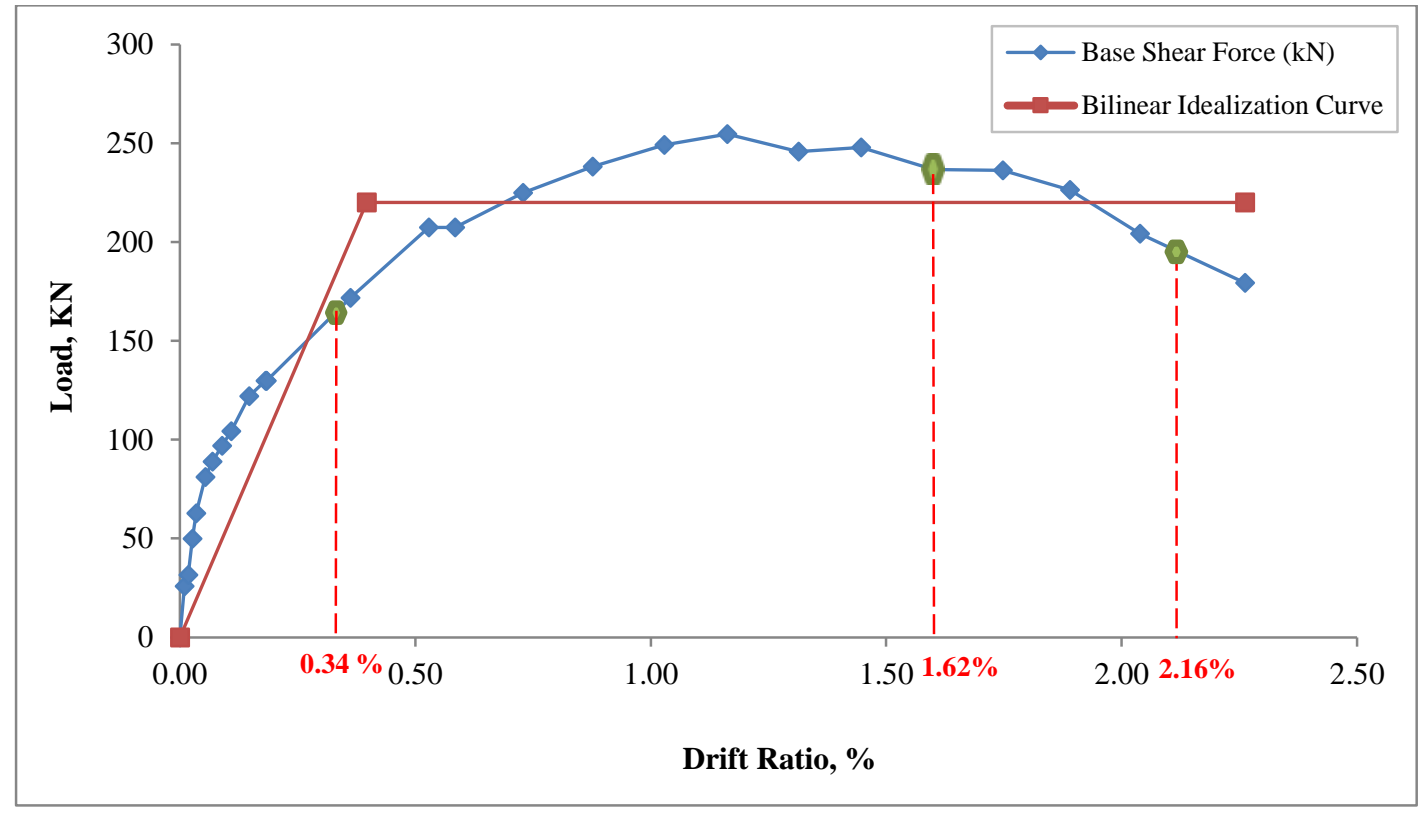

Figure 26. Performance Levels of RC Frame with Specimen $1(1$ inch $=25.4 \mathrm{~mm})$

The IO performance level was at a drift of $0.36 \%$. At a drift of $1.76 \%$ drift LS performance level was noticed; while the CP performance level, which is at 20\% degradation of the load was at $2.35 \%$ after an extrapolation.

The Performance Levels of Specimen-2 are shown in Figure 27, with IO $=0.34 \%$ drift, $\mathrm{LS}=1.62 \%$ drift and $\mathrm{CP}=$ $2.16 \%$ drift. The LS performance level of specimen-2 as compare to specimen-1 was decreased by $7.95 \%$ while CP performance of was decreased by $8.08 \%$, therefore specimen 1 is more venerable to lateral loading as compare to specimen-2.

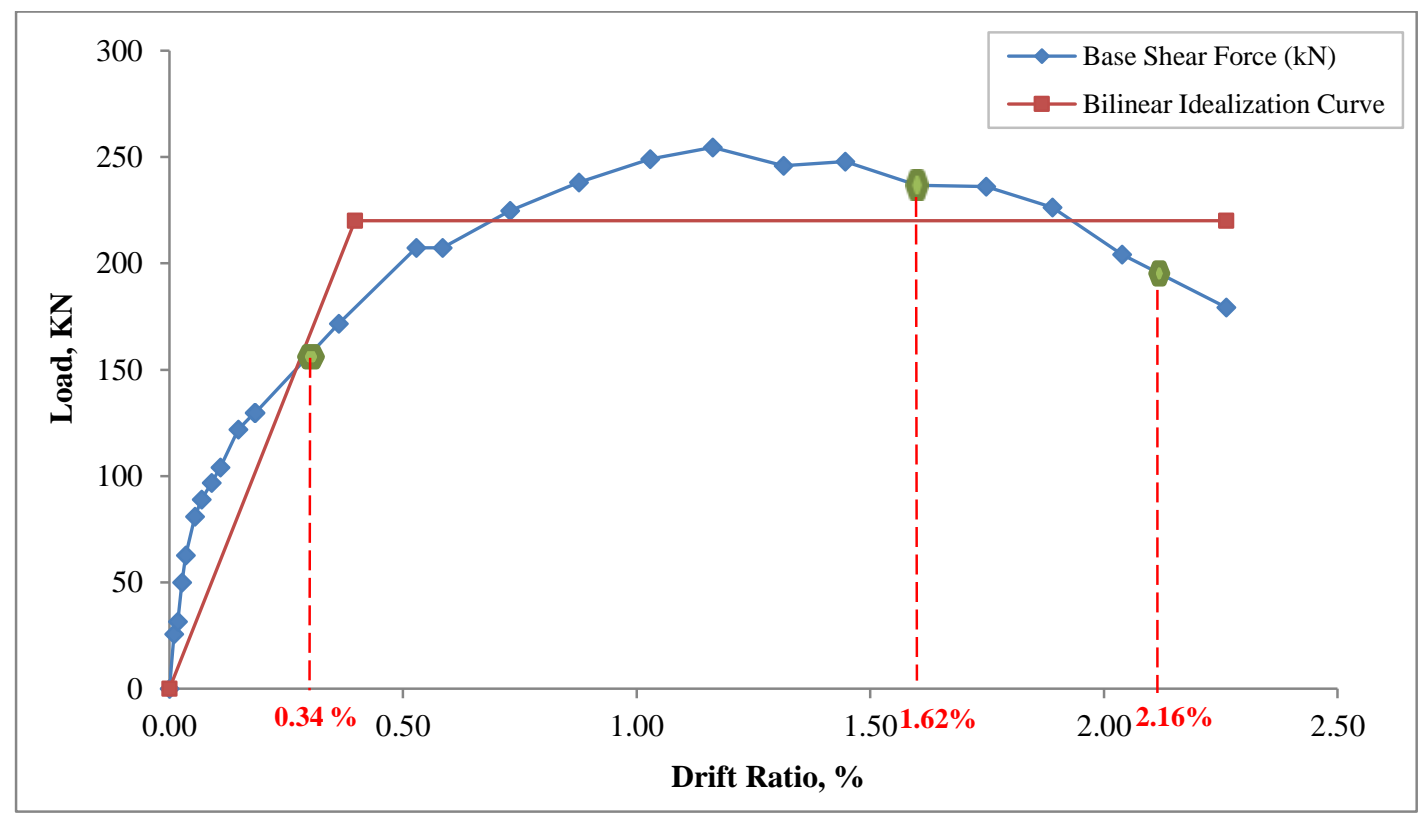

Figure 27. Performance Levels of Specimen $2(1 \mathrm{inch}=25.4 \mathrm{~mm})$

\section{Conclusions and Recommendations}

Pakistan is one of the seismically dynamic countries and has encountered some overwhelming earthquakes in the past time, e.g., 2005 earthquake of Kashmir (7.6 on Richter scale) which resulted in substantial economic, social and human losses. Approximately 0.4 million houses were wholly and somewhat damaged. Dominant parts of the damaged structures were infill walls. These infill walls are sometimes provided with openings, i.e. door and windows for entrance and air etc. to find out the effect of the openings on the infill wall. Two full scales perforated reinforced concrete frames were constructed in the laboratory-based on the current construction practices in Pakistan. One RC frame having eccentric door and window, while the other has a window at its centre. Both the frames were tested 
against reverse cyclic loading (quasi-static test). After performing the test, it was concluded that the door window junction being weak undergoes initial cracking. The maximum load taken by RC frame with door and window (specimen-1) was $148.65 \mathrm{kN}$ (33.42 kips) while RC frame with a window only (specimen-2) reached to a maximum load of $252.16 \mathrm{kN}$ (56.69 kips). The effective stiffness of specimen-1 and specimen-2 were $6.61 \mathrm{kN} / \mathrm{m}$ (58.50kip/in) and $12.7142 \mathrm{kN} / \mathrm{m}(112.53 \mathrm{kip} / \mathrm{in})$ respectively. From the hysteresis loop, it is concluded that greater energy is dissipated in specimen 2 (infilled frame with window opening only) because of the internal friction between the infilled wall and the frame, and a higher number of cracks within the infilled wall. The displacement ductility $(\mu \mathrm{D})$ and Response modification factor (R) of specimen-1 was 7.05 and 6.95, whereas that of specimen-2 was found 6.06 and 7.09, respectively. Response modification factor is sensitive to the geometric configuration as compared to the single value as suggested in the available codes of practice. Immediate Occupancy (IO), Life Safety (LS) and Collapse Prevention (CP) were $0.36,1.76$ and $2.35 \%$ drift respectively whereas IO, LS and CP were found $0.34 \%, 1.62 \%$ and $2.16 \%$ of drift respectively for specimen-2. The quantity of infilled wall decreased the performance levels along with the response modification factor.

It is worthy to note that proper attention should be provided to strengthen the door-window junction during construction as this is a weak zone, and therefore it can undergo initial cracking if special care is not provided. Since first-class bricks comprise of better mechanical properties such as strength, therefore these should be strictly used as infill material to avoid any catastrophe. Initial on-site testing, as well as laboratory testing, is required before using in the construction. The corner of windows should be filled with a material so that stress concentration at the corner is minimized.

For the future study, the following are recommendations:

- The same frames should be studied again with the opening fastened with a metallic frame;

- The effect of black masonry infilled RC with openings should be studied;

- The location of the window should be changed and then again should be compared with the specimen 2 .

\section{Funding}

This work was sponsored by Higher Education Commission, Government of Pakistan within the funded projects.

\section{Acknowledgements}

The Authors highly acknowledges the support of laboratories management the testing facilities management at the University of Engineering and Technology, Peshawar, Pakistan for allowing to utilize the facilities for the experimental testing. The Authors also acknowledges the reviewer suggestions made during the review phase of the publication.

\section{Conflicts of Interest}

The authors declare no conflict of interest.

\section{Notations}

$\begin{array}{llll}\mathrm{W}_{\mathrm{w}}= & \text { Weight of wet bricks }(\text { gram }), & \mathrm{G}_{\mathrm{m}}= & \text { Modulus of rigidity } \\ \mathrm{W}_{\mathrm{d}}= & \text { Weight of dry brick, }(\text { gram }), & \mathrm{Ss}= & \text { Vertical diagonal shear stress } \\ \mathrm{A}_{\mathrm{s}}= & \text { Surface area of brick in contact with water }\left(\mathrm{in}^{2}\right) . & \mathrm{PD}= & \text { Applied load } \\ \mathrm{R}= & \text { Response modification factor } & \mathrm{A}_{\mathrm{n}}= & \text { Net area of prism } \\ \mathrm{t}_{\mathrm{u}}= & \text { Principal tensile strength of masonry specimen, } & \mathrm{W}_{\mathrm{d}}= & \text { Weight of dry brick in gram } \\ \mathrm{P}_{\mathrm{u}}= & \text { Ultimate applied vertical load, } & \mathrm{W}_{\mathrm{w}}= & \text { Weight of the wet brick gram. } \\ \mathrm{A}_{\mathrm{n}}= & \text { Net area of prism. } & \mathrm{E}_{\mathrm{m}}= & \text { Modulus of elasticity }\end{array}$

\section{References}

[1] Ricci, Paolo, Maria Teresa De Risi, Gerardo Mario Verderame, and Gaetano Manfredi. "Influence of Infill Distribution and Design Typology on Seismic Performance of Low- and Mid-Rise RC Buildings." Bulletin of Earthquake Engineering 11, no. 5 (May 2, 2013): 1585-1616. doi:10.1007/s10518-013-9453-4.

[2] Stavridis, Andreas, I. Koutromanos, and P. B. Shing. "Shake-Table Tests of a Three-Story Reinforced Concrete Frame with Masonry Infill Walls." Earthquake Engineering \& Structural Dynamics 41, no. 6 (September 27, 2011): $1089-1108$. doi:10.1002/eqe.1174.

[3] Dautaj, Arton D., Qani Kadiri, and Naser Kabashi. "Experimental Study on the Contribution of Masonry Infill in the Behavior of RC Frame under Seismic Loading.” Engineering Structures 165 (June 2018): 27-37. doi:10.1016/j.engstruct.2018.03.013. 
[4] Shing, P Benson, and Armin B Mehrabi. "Behaviour and Analysis of Masonry-Infilled Frames." Progress in Structural Engineering and Materials 4, no. 3 (2002): 320-331. doi:10.1002/pse.122.

[5] Lodi, Sarosh Hashmat, and Aslam Faqeer Mohammad. "Nonlinear static analysis of an infill framed reinforced concrete building." In 15th World Conference on Earthquake Engineering. (2012).

[6] Yuen, Y.P., and J.S. Kuang. "Nonlinear Seismic Responses and Lateral Force Transfer Mechanisms of RC Frames with Different Infill Configurations.” Engineering Structures 91 (May 2015): 125-140. doi:10.1016/j.engstruct.2015.02.031.

[7] Negro, P., and A. Colombo. "Irregularities Induced by Nonstructural Masonry Panels in Framed Buildings." Engineering Structures 19, no. 7 (July 1997): 576-585. doi:10.1016/s0141-0296(96)00115-0.

[8] Koutromanos, Ioannis, Andreas Stavridis, P. Benson Shing, and Kaspar Willam. "Numerical Modeling of Masonry-Infilled RC Frames Subjected to Seismic Loads." Computers \& Structures 89, no. 11-12 (June 2011): $1026-1037$. doi:10.1016/j.compstruc.2011.01.006.

[9] Mehrabi, Armin B., P. Benson Shing, Michael P. Schuller, and James L. Noland. "Experimental Evaluation of Masonry-Infilled RC Frames." Journal of Structural Engineering 122, no. 3 (March 1996): 228-237. doi:10.1061/(asce)07339445(1996)122:3(228).

[10] Crisafulli, Francisco J., and Athol J. Carr. "Proposed Macro-Model for the Analysis of Infilled Frame Structures." Bulletin of the New Zealand Society for Earthquake Engineering 40, no. 2 (June 30, 2007): 69-77. doi:10.5459/bnzsee.40.2.69-77.

[11] P. H. Feenstra and R. de Borst, “Aspects of robust computational modeling for plain and reinforced concrete,” Heron, 1993.

[12] Khalilzadeh Vahidi, Ebrahim, and Reza Moradi. "Numerical Study of the Force Transfer Mechanism and Seismic Behavior of Masonry Infilled RC Frames with Windows Opening.” Civil Engineering Journal 5, no. 1 (January 27, 2019 ): 61. doi:10.28991/cej-2019-03091225.

[13] Naqash, Muhammad Tayyab. "Study on the fundamental period of vibration of steel moment resisting frames." International Journal of Advanced Structures and Geotechnical Engineering 3, no. 01 (2014): 01-06.

[14] M. T. Naqash, G. De Matteis, and A. De Luca, "European Versus American Practice for Seismic Design of Steel Moment Resisting Frames (MRFS),” in XXIII Italian steel conference, (2011): 599-610.

[15] ATC-43, "FEMA 306. Evaluation of Earthquake Damaged Concrete and Masonry Wall Buildings. Basic Procedures Manual," (1998).

[16] ATC, "FEMA 307. Evaluation of Earthquake Damaged Concrete and Masonry Wall Buildings. Technical Resources," Management, (1998).

[17] Shah, Syed Azmat Ali, Junaid Shah Khan, Syed Muhammad Ali, Khan Shahzada, Waqar Ahmad, and Junaid Shah. "Shake Table Response of Unreinforced Masonry and Reinforced Concrete Elements of Special Moment Resisting Frame." Advances in Civil Engineering 2019 (July 7, 2019): 1-17. doi:10.1155/2019/7670813.

[18] Ali, Wajid, Syed Azmat Ali Shah, Khan Shahzada, Syed Muhammad Ali, and Sajjad Wali Khan. "Retrofitting of Infilled Frame in Reinforced Concrete Structure.” July 2020 39, no. 3 (July 1, 2020): 475-488. doi:10.22581/muet1982.2003.03.

[19] Naqash, Muhammad Tayyab, Gianfranco De Matteis, and Antonio De Luca. "Seismic design of steel moment resisting frames-European versus American practice." NED University Journal of Research 9, no. 2 (2012): 45-60.

[20] Khoso, Salim, Muhammad Tayyab Naqash, Sadaf Sher, and Zeeshan Saeed. "An Experimental Study on Fiberly Reinforced Concrete Using Polypropylene Fibre with Virgin and Recycled Road Aggregate." Architecture, Civil Engineering, Environment 11, no. 1 (2018): 73-80. doi:10.21307/acee-2018-007.

[21] Naqash, Muhammad Tayyab, and Qazi Umar Farooq. "Performance of Rigid Steel Frames under Adequate Soil Conditions Using Seismic Code Provisions.” Open Journal of Civil Engineering 08, no. 02 (2018): 91-101. doi:10.4236/ojce.2018.82008.

[22] American Society of Testing and Materials, "ASTM C136/C136M - 19: Standard Test Method for Sieve Analysis of Fine and Coarse Aggregates,” Annu. B. ASTM Stand., (2014).

[23] ASTM C109, "Standard Test Method for Compressive Strength of Hydraulic Cement Mortars," Annu. B. ASTM Stand., (2000).

[24] ASTM International, "ASTM C 1314-18, Standard Test Method for Compressive Strength of Masonry Prisms,” Am. Soc. Test. Mater., (2018).

[25] ASTM C67, “ASTM C67:2008 Standard test methods for sampling and testing brick and structural clay tile," ASTM Int., (2001).

[26] ASTM E519 / E519M - 15 "Standard Test Method for Diagonal Tension (Shear) in Masonry Assemblages" ASTM Int., (2010). 
[27] ASTM C39/C 39M, “Test Method for Compressive Strength of Cylindrical Concrete Specimens 1,” ASTM Int., (2016).

[28] Dehghani, Ayoub, Fariborz Nateghi-Alahi, and Gregor Fischer. "Engineered Cementitious Composites for Strengthening Masonry Infilled Reinforced Concrete Frames." Engineering Structures 105 (December 2015): 197-208. doi:10.1016/j.engstruct.2015.10.013.

[29] American Society of Civil Engineers. "Minimum design loads and associated criteria for buildings and other structures." American Society of Civil Engineers, (2017). 